\title{
Silver Nanomaterials for Wound Dressing Applications
}

\author{
Priya Dharshini Krishnan ${ }^{1}$, Dominik Banas ${ }^{2,3}$, Ramya Devi Durai ${ }^{1}$, Daniil Kabanov ${ }^{2,3}$, \\ Bozena Hosnedlova $\left.{ }^{4}{ }^{(}\right)$, Marta Kepinska $\left.{ }^{5}{ }^{(}\right)$, Carlos Fernandez ${ }^{6}$, Branislav Ruttkay-Nedecky ${ }^{3,4,7}$, \\ Hoai Viet Nguyen ${ }^{8}$, Awais Farid ${ }^{9}$, Jiri Sochor ${ }^{4}(\mathbb{D}$, Vedha Hari B. Narayanan $1, * \mathbb{(}$ \\ and Rene Kizek ${ }^{3,4,5,10, *}$
}

1 Department of Pharmacy, School of Chemical and Biotechnology, SASTRA Deemed University, Thanjavur 613-401, India; p.dharshi14@gmail.com (P.D.K.); ramya@scbt.sastra.edu (R.D.D.)

2 Department of Biochemistry, Faculty of Science, Masaryk University, Kamenice 753/5, 62500 Brno-Bohunice, Czech Republic; dominik.banass@gmail.com (D.B.); dac100@mail.ru (D.K.)

3 Department of Research and Development, Prevention Medicals, Tovarni 342, 74213 Studenka-Butovice, Czech Republic; brano.ruttkay@seznam.cz

4 Department of Viticulture and Enology, Faculty of Horticulture, Mendel University in Brno, Valticka 337, 69144 Lednice, Czech Republic; bozena.hosnedlova@post.cz (B.H.); jiri.sochor@mendelu.cz (J.S.)

5 Department of Biomedical and Environmental Analyses, Faculty of Pharmacy, Wroclaw Medical University, Borowska 211, 50-556 Wroclaw, Poland; marta.kepinska@umed.wroc.pl

6 School of Pharmacy and Life Sciences, Robert Gordon University, Garthdee Road, Aberdeen AB10 7QB, UK; c.fernandez@rgu.ac.uk

7 Department of Molecular Pharmacy, Faculty of Pharmacy, Masaryk University, Palackeho 1946/1, 61200 Brno, Czech Republic

8 Research Center for Environmental Monitoring and Modeling, University of Science, Vietnam National University, 334 Nguyen Trai Street, Hanoi 100000, Vietnam; nguyenviethoai@hus.edu.vn

9 Division of Environment and Sustainability, Hong Kong University of Science and Technology, Room 4412, Clear Water Bay, Kowloon, Hong Kong, China; awais@ust.hk

10 Department of Pharmacology and Toxicology, Faculty of Pharmacy, Masaryk University, Palackeho 1946/1, 61200 Brno, Czech Republic

* Correspondence: vedhahari@scbt.sastra.edu (V.H.B.N.); kizek@sci.muni.cz (R.K.); Tel./Fax: +91-4362-264101 (ext.2151) (V.H.B.N.); +42-05-4156-2820 (R.K.)

Received: 13 July 2020; Accepted: 25 August 2020; Published: 28 August 2020

\begin{abstract}
Silver nanoparticles (AgNPs) have recently become very attractive for the scientific community due to their broad spectrum of applications in the biomedical field. The main advantages of AgNPs include a simple method of synthesis, a simple way to change their morphology and high surface area to volume ratio. Much research has been carried out over the years to evaluate their possible effectivity against microbial organisms. The most important factors which influence the effectivity of AgNPs against microorganisms are the method of their preparation and the type of application. When incorporated into fabric wound dressings and other textiles, AgNPs have shown significant antibacterial activity against both Gram-positive and Gram-negative bacteria and inhibited biofilm formation. In this review, the different routes of synthesizing AgNPs with controlled size and geometry including chemical, green, irradiation and thermal synthesis, as well as the different types of application of AgNPs for wound dressings such as membrane immobilization, topical application, preparation of nanofibers and hydrogels, and the mechanism behind their antimicrobial activity, have been discussed elaborately.
\end{abstract}

Keywords: nanosilver; therapeutic activity; antibacterial effect; synthesis route 


\section{Introduction}

Infected wounds represent a complex, non-trivial, problem which seriously jeopardizes the health and life of patients. One of the most frequent problems is a chronic ulcer with deep tissue damage in patients with diabetes, connected with abnormal fibroblast and keratinocyte proliferation, reduced cell migration and decreased angiogenesis, which can lead to impairment of vascularization, delayed wound contraction and subsequent formation of non-healing diabetic wounds [1]. Not only diabetic wounds but also leg ulcers, arterial insufficiency, pressure ulcers and burns impose substantial morbidity and mortality, deeply affecting quality of life, with high economic burden [2]. Generally, wounds can be divided into acute and chronic [3]. When chronic wounds were analyzed in a mouse model, a huge diversity of microorganisms formatting biofilm (for example, Enterobacter cloacae, Streptococcus thermophilus, Propionibacterium acnes) and without biofilm formation (Achromobacter xylosoxidans) were observed. Biofilms as sessile microbial consortia established in a three-dimensional structure are an important strategy implemented by microorganisms to survive in sometimes harsh environmental conditions [4]. Biofilms within the in vitro environment only are often referred to as immature when they have been growing for less than $24 \mathrm{~h}$ and mature when they have been growing for more than $24 \mathrm{~h}$ [5]. The ratio between different biofilm and non-biofilm creating bacterial types in a wound is dependent on type and time of treatment [6]. Thus, because a variety of different bacterial species live in the wounds, there is a widely acknowledged need for new antibacterial agents to address the global increase in resistance [7]. The level of resistance, especially against traditional antibiotics (for example, methicillin-resistant Staphylococcus aureus [8], penicillin-resistant Enterococcus faecalis [9] or multiresistant Mycobacterium tuberculosis [10]) is still increasing, and the rising incidence of antimicrobial resistance among pathogenic bacteria is one of the greatest healthcare challenges facing humanity today [11]. Thus, new approaches to overcome bacterial resistance are being tried, comprising by using plant extracts [12] or a combination of antibiotics and other antibacterial materials [13], especially nanomaterials, which comprise unary [14], binary (AgAu, AgPt NPs) [15,16] or multicomponent materials (CdZnSe-CdZnS nanoalloy) [17]. Nanotechnology is nowadays a flourishing scientific field, which associates nanoparticles with extraordinary functions and size-dependent physicochemical properties, differing significantly from the macroscopic forms of these elements. Nanomaterials comprise nanoparticles (NPs), which can be divided into inorganic and organic nanoparticles and nanocomposites, which can be grouped into the porous material, colloids, copolymers and gels. Finally, the applications of nanoparticles and nanocomposites in scaffolds and coatings are via hydrogels, nanofibers and films (Figure 1). Over the years, inorganic nanoparticles have been explored extensively in nanomedicine [18], electronics [19], drug delivery [20], biomedical devices [21], food sectors as package material [22,23], and dentistry such as: prosthetic, restoration, endodontic, orthodontic, periodontal and dental implant treatment. In addition, an improvement of mechanical properties of dental materials; inhibition of adhesion and bacteria growth of Escherichia coli, Streptococcus mutans, Enterococcus faecalis, Pseudomonas aeruginosa, S. aureus and the fungus Candida albicanshave been observed [24], etc. 
NANOPARTICLES

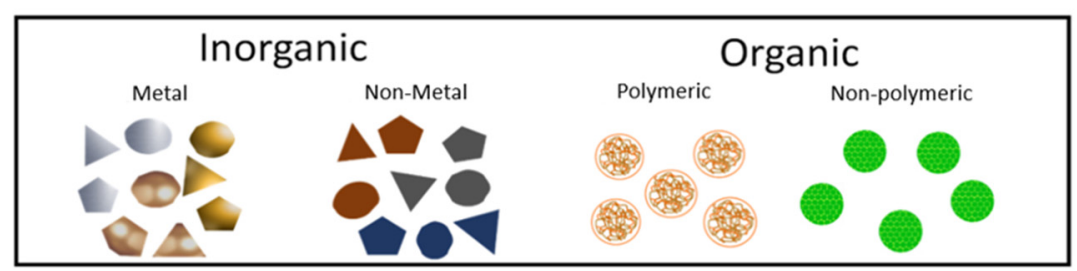

NANOCOMPOSITES

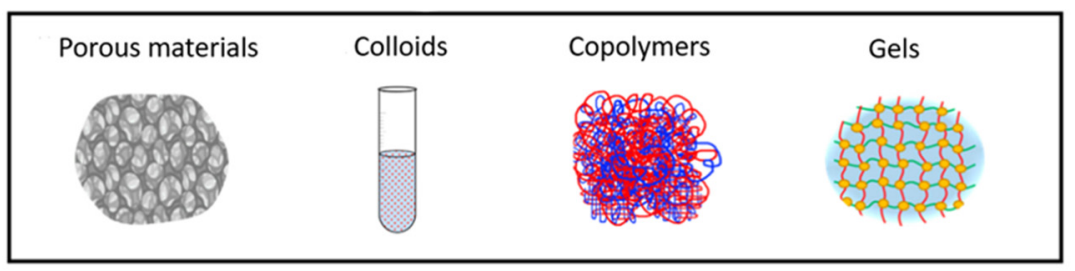

COATINGS AND SCAFFOLDINGS

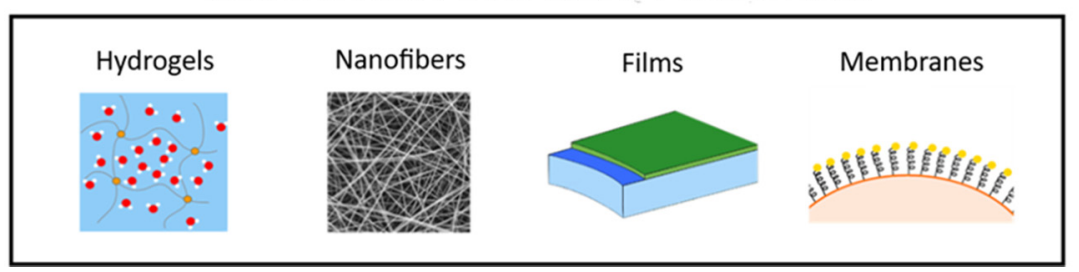

Figure 1. Nanomaterials with potential use for wound treatment. Nanomaterials cover several groups of materials including nanoparticles, nanocomposites and different coatings and scaffolding materials. Nanoparticles can be divided into two groups depending on their chemical basis, which comprises inorganic (metal-Ag, Au, Zn, Cu etc.; non-metal—for example, Se) and organic (polymeric and non-polymeric) nanoparticles. From the perspective of nanocomposites, four groups can be recognized: porous materials, colloids, copolymers and gels. For the wound coating and scaffolds, hydrogels, nanofibers, films and membranes can be used. Adapted from [25] under a CC BY 4.0 license.

Among the several inorganic NPs, silver NPs (AgNPs), due to their novel chemical, biological and physical properties as compared to their bulk form, have attracted the interest of researchers from the whole academic sphere. AgNPs have typical physical and chemical properties-for example, high thermal and electrical conductivity [26], surface-enhanced Raman scattering [27], chemical stability [28], catalytic activity [29] and non-linear optical behavior [30]. These properties take AgNPs to the top of the priority list, and they can be used in inks, in electronics and for medical purposes. Additionally, AgNPs are commonly known for their antibacterial, antifungal and antiviral properties. Mechanisms of effectivity comprise the disrupting of cell membranes, interaction with sulfhydryl groups of proteins, inactivation of respiratory enzymes, DNA modification, etc. (Figure 2). Microorganisms, however, have also mechanisms to adapt and to resist to metals (for example, reduced uptake, through efflux, chemical modification of metals, etc.) [31].

Thus, there is a need for a better understanding of these parameters on the efficacy and toxicity of AgNPs. Wide variety in size, concentration, shape, materials, polymers and surfaces of AgNPs are commonly being used [32].

The antimicrobial properties of AgNPs have been described and proven in various in vitro and in vivo studies, and their applications in food packaging, soaps, cosmetics, fabrics and wound dressing materials have also been reported [33]. There are a number of methods for antimicrobial susceptibility testing (AST) of bacteria, which can be divided into diffusion methods and dilution methods [34,35]. The most used diffusion methods are the agar disk-diffusion method and antimicrobial gradient method (Etest). The most used dilution methods are the broth dilution method and agar dilution method [36]. The broth dilution method can be further divided into the broth macrodilution method and broth 
microdilution method [36]. The broth macrodilution method has been standardized by the Clinical and Laboratory Standards Institute (CLSI) for testing bacteria that grow aerobically [37]. The broth microdilution method is standardized by CLSI for both anaerobic [38] and aerobic bacteria [39]. As a representative example of the agar plate disk diffusion test [40] and the broth microdilution test (a measurement of growth curves) [41], our own experimental results for green-synthesized nanoparticles are shown in Figure 3.

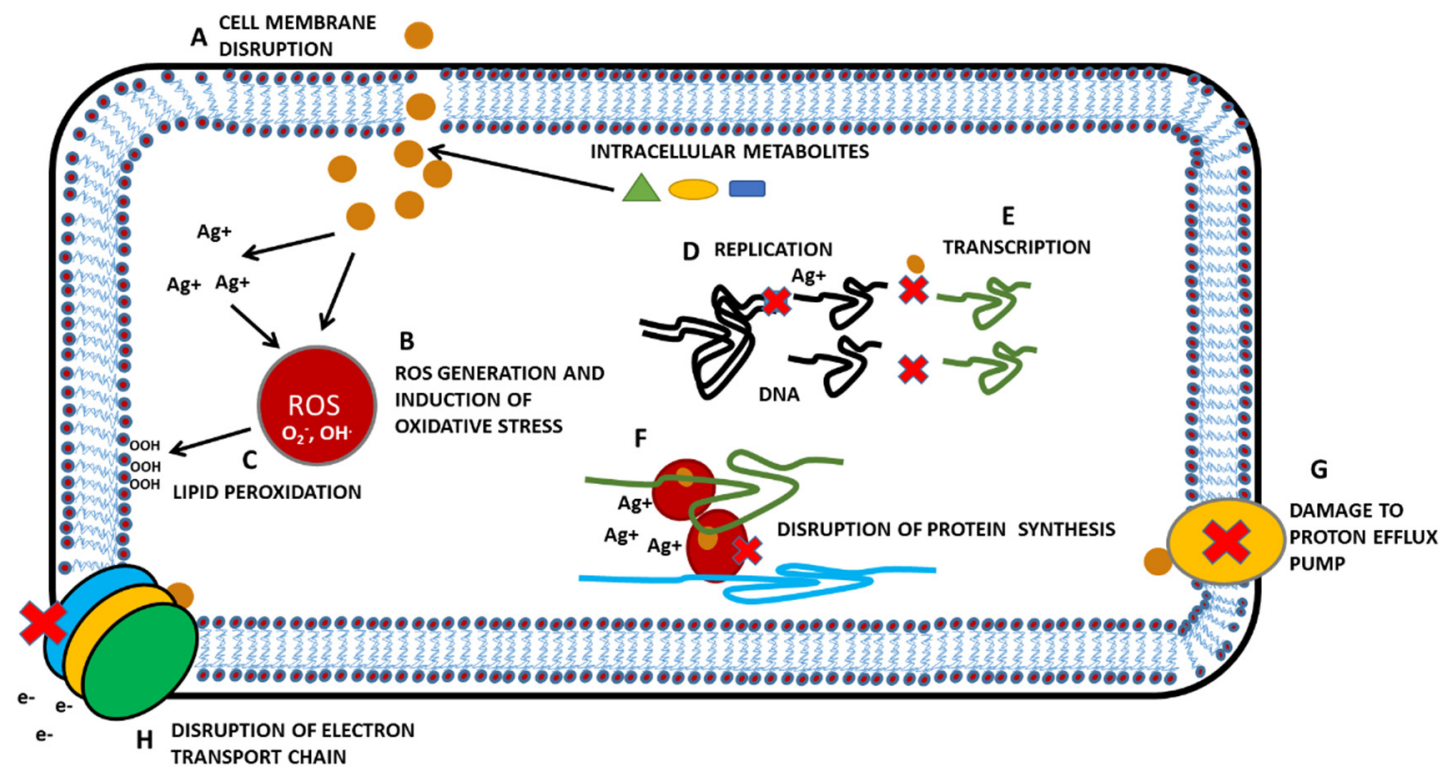

Figure 2. Effect of silver nanoparticles (AgNPs) on the single bacterial cell. (A) AgNPs penetrate through the cell membrane and cause its disruption; intracellular metabolites are released via the disrupted membrane. (B) AgNPs release silver ions $\left(\mathrm{Ag}^{+}\right)$to generate reactive oxygen species (ROS) and induce oxidative stress. (C) ROS are, for example, responsible for lipid peroxidation, which significantly changes the distribution of intracellular and extracellular metabolites and causes a change in membrane permeability, because lipid strains are repulsed. Interaction of $\mathrm{AgNPs}$ and $\mathrm{Ag}^{+}$with proteins can affect (D) DNA enzymatic replication machinery, (E) DNA transcription, (F) translation of DNA to polypeptide/protein chain on ribosomes (red-brown ovals), $(\mathbf{G})$ proton efflux pumps, $(\mathbf{H})$ electron transport chain (represented by blue, yellow and green ovals) and creation of energetic sources of cells (ATP). Adapted from [31], Copyright Springer Nature, 2013.

AgNPs are also used in water filter membranes for point-of-care water disinfection, utilizing their antimicrobial properties [42]. The AgNPs can be used in all physical forms-for example, in colloidal form (in enamel coating and paints), liquid form (cosmetics) and solid form (blended with polymer scaffolds). For wounds, different types of treatment with silver and AgNPs were proposed and they are shown in Figure 4. Application of nanomaterials on the wound can be direct, in the form of powdered AgNPs or their solutions. The second possibility is the use of non-compact materials for wound treatment as water-soluble polymers and hydrogels. The third possibility is the use of solid polymers (fibers, membranes and films). The role of nanomaterial wound dressings in the wound healing process, in general, is shown in Figure 5. One problematic aspect of AgNPs wound dressings is that there are reported cases of bacterial resistance to AgNPs. For example, resistance to AgNPs attributed to sil genes has been reported in clinical isolates of Klebsiella pneumoniae and Enterobacter cloacae from burn cases [43]. Thus, the continuous development of a new combination of nanomaterials, antibiotics, polymers, methods of incorporation and types of reduction of silver to obtain various shapes of NPs is essentially necessary. 

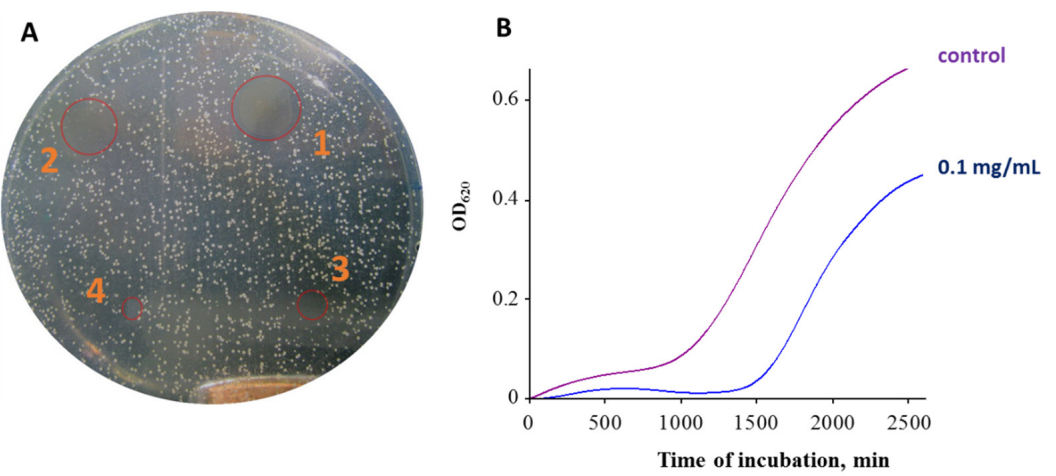

Figure 3. Two basic methods of screening of the antibacterial effect: (A) Effect of AgNPs in concentrations of 5 (1), 2.5 (2), 1.25 (3) and $0.625 \mathrm{mg} / \mathrm{mL}$ (4) in the agar plate disk diffusion test on S. aureus cells after $24 \mathrm{~h}$ of incubation. Growth inhibition zones are marked by red circles. (B) The growth curve of $S$. aureus without (control) or with $0.1 \mathrm{mg} / \mathrm{mL}$ AgNPs showed optical density of $620 \mathrm{~nm}\left(\mathrm{OD}_{620}\right)$, dependent on the time of growth.

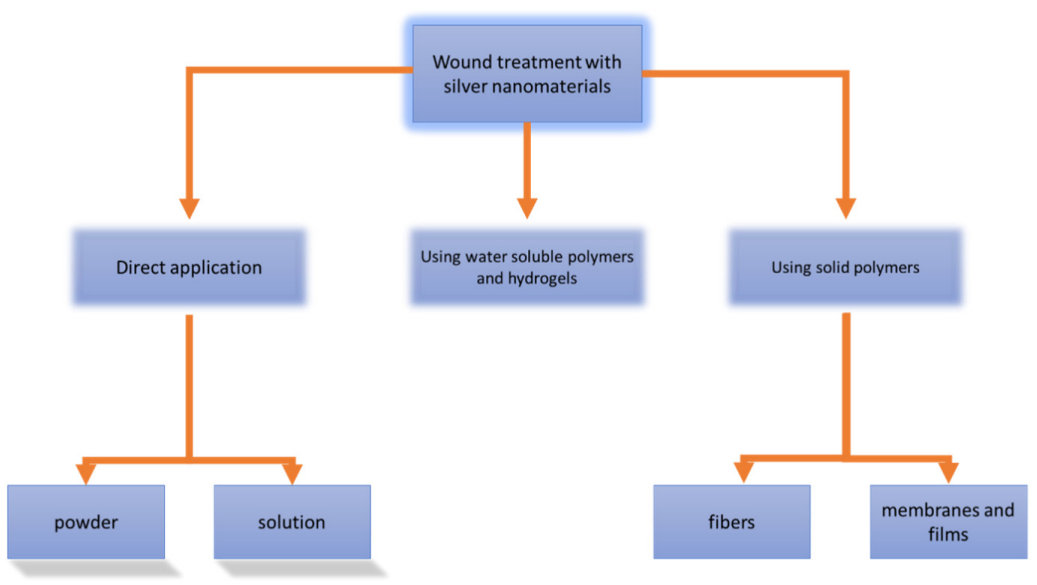

Figure 4. Wound treatment with silver nanomaterials. Nanomaterials can be applied directly to the wound (solution or powder nanoparticles) or nanomaterial-containing cloth and fabrics can be used. Hydrogels and water-soluble polymers are being used as non-compact materials (they are easily rubbed on the skin); on the contrary, compact materials comprising fibers, membranes and films are firm and non-soluble.

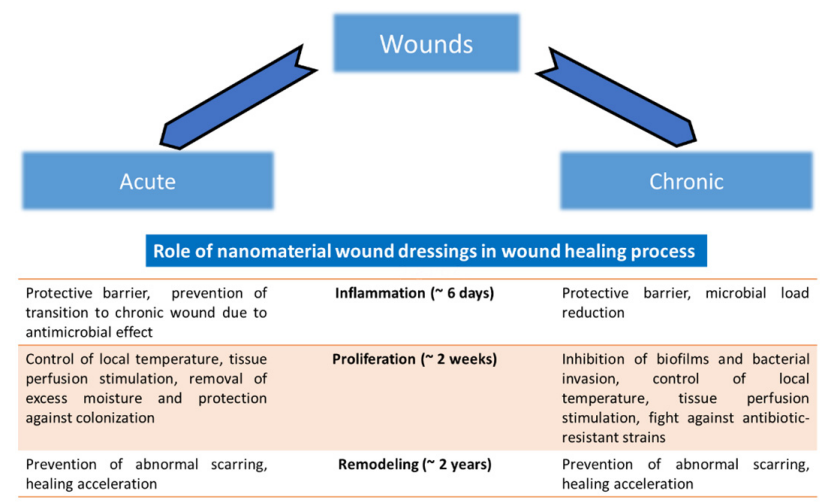

Figure 5. Summary of antimicrobial wound dressings with nanomaterials. The role of wound dressings using nanomaterials in various phases of wound healing (which comprise inflammation, proliferation and remodeling of the wound) is shown (the approximate duration of each phase is indicated in parentheses). Mostly, the effect is achieved due to the physical protection of the wound, acceleration of healing and broad antimicrobial action. Adapted from [25] under a CC BY 4.0 license. 


\section{Methodology of the Review}

The methodology of this review is summarized in Figure 6.

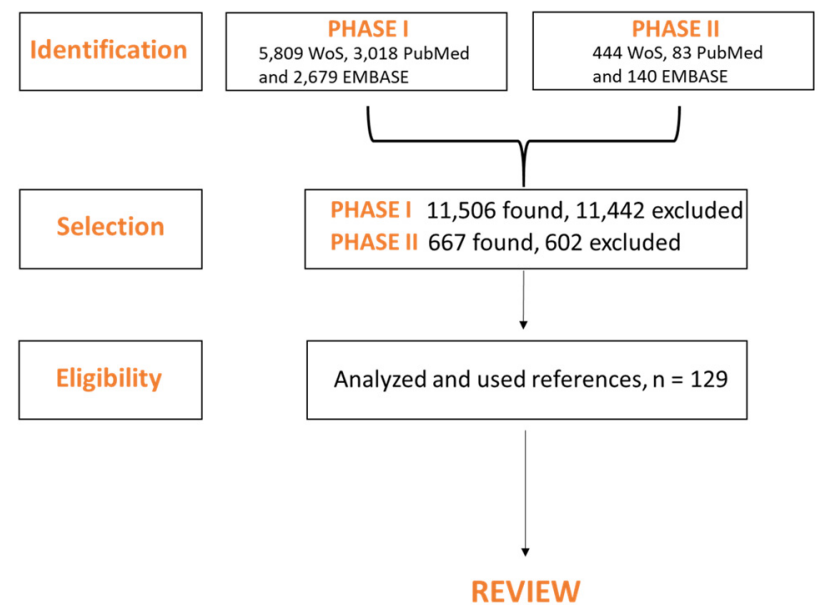

Figure 6. Flowchart of choice of articles for review, "Silver Nanoparticles for Wound Dressing Applications". In the first phase, articles were searched according to the following keywords: "silver nanoparticles in wounds"; "silver nanoparticles and therapeutic application"; "chemical synthesis of AgNPs"; "green synthesis of AgNPs"; "irradiation synthesis of AgNPs"; "thermal synthesis of AgNPs". The following databases were used: Web of Science (WoS) core collection; PubMed and Embase, searching since 2000. Completely, more than 11,000 articles were found (5809 WoS, 3018 PubMed and 2679 Embase). Condensate extraction of articles from this phase was used for writing introduction and parts about the synthesis of particles. In the second phase, we were interested only in articles with the keywords "AgNPs for wound dressing applications". More than 600 articles were found (444 WoS, 83 PubMed and 140 Embase). Some of these articles were used for writing the main section concerning different means of preparing AgNPs wound dressings. It is seen that using AgNPs, especially in wound dressings, comprises the effort of many work teams from around the world; thus, it is impossible to describe all techniques, materials and types of synthesis of AgNPs. We tried to choose several representative examples for all types of synthesis and the most frequent using polymeric materials to give the reader a complex view of the problematic nature of using AgNPs in wound dressing. The articles which were preferred were articles from 2007, which describe mainly the use of AgNPs. The articles were selected also upon impact factor (average impact factor is 6.31) and quartile of the journal (Q1 and Q2). Finally, 129 articles were chosen to write this review.

This paper aims to summarize the various methods adopted for the synthesis of AgNPs that include chemical, green, irradiation and thermal synthesis and routes of application of these nanoparticles through membrane immobilization, topical application, nanofibers and hydrogel system for wound dressing (see Figure 1). In this review paper, every aspect of AgNPs, from synthesis to their utilization in wound dressing applications against various bacterial and fungal strains, has been discussed.

\section{Synthesis of AgNPs}

This review aims to conclude the newest findings of the antibacterial effect of AgNPs connected with covering materials for wound dressing and healing. As mentioned above, four types of AgNPs synthesis are described, namely chemical, green, irradiation and thermal. In this section, the basic characteristics of each type of synthesis are briefly described. In chemical synthesis, the Turkevich method and Brust-Schiffrin synthesis are mainly used [43]. The Turkevich method is based on the reduction of the boiling solution of silver salt with a solution of citrate salt. The Brust-Schiffrin method is mainly used for golden nanoparticles, but applications for other metals were also described [44]. Stabilization of AgNPs synthesis is ensured by using surfactants (thiols, amines, acids and alcohols) or polymers (poly(vinyl alcohol), poly(vinylpyrrolidone), poly(ethylene glycol), poly(methacrylic 
acid) and polymethyl methacrylate) [45]. Green synthesis represents a low-cost, environmentally friendly way of producing AgNPs without using high temperatures and pressures [46]. Typically, the plant [46-50], fungus [51-53] or bacteria extract is mixed with silver ions containing salt (silver nitrate is mainly used [46-53]) and bioactive molecules of extracts reduce silver ions to elementary silver. A huge advantage of using plant extracts is the fact that many plants contain health-beneficial compounds, also known from their use in conventional medicine (for example, paclitaxel, vincristine or artemisinin) [54]. After nucleation, the AgNPs can be precipitated with alcohol [55] (for example, methanol, ethanol or isopropyl alcohol). Model synthesis is shown in Figure 7.

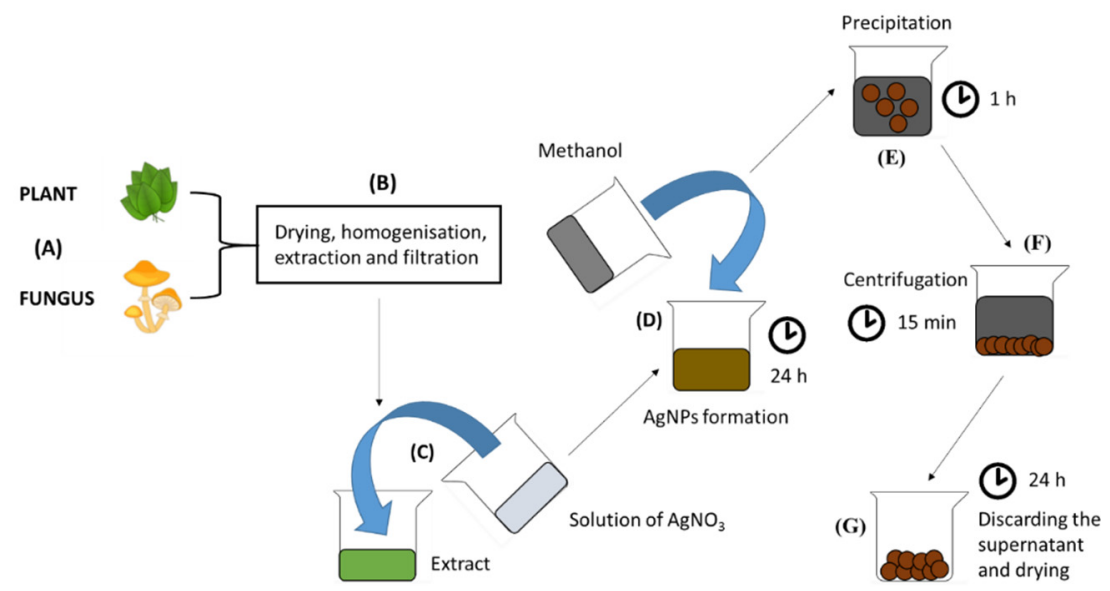

Figure 7. The process of preparation of AgNPs. (A) A plant/fungus is (B) homogenized, extracted, centrifugated and filtrated; subsequently $(\mathrm{C})$, silver ions in the form of $0.1 \mathrm{M} \mathrm{AgNO}_{3}$ are added in a 1:1 (v/v) ratio. (D) AgNPs are formed within $24 \mathrm{~h}$. (E) AgNPs are precipitated with methanol in a 1:1 $(v / v)$ ratio for $1 \mathrm{~h}$. (F) The solution of AgNPs is centrifuged for $15 \mathrm{~min}, 4000 \mathrm{~g}$. (G)The supernatant is discarded and AgNPs are dried by lyophilization for $24 \mathrm{~h}$.

The process of reduction of $\mathrm{Ag}^{+}$to $\mathrm{Ag}^{0}$ with biomolecules relates to the high reduction power of the biomolecule cocktail. Depending on the extract composition, the velocity of stirring and time of nucleation of AgNPs, AgNPs with different shapes can be obtained (Figure 8).

Irradiation synthesis [56-58] is connected with radiation of precursors or intermediate products of reaction with electromagnetic radiation with different wavelengths. Only specialized laboratories with a suitable radiation source and in respect to the difficult legislature can achieve this type of synthesis. Jia et al. [56] prepared gold nanoclusters using triple helix glucan Lentiman via microwave-assisted synthesis and subsequently employed them as seeds for Ag-Au nanoparticle alloy; these nanoparticles increase in size with higher Ag amounts [56]. Mixed cellulose nanofibrils and AgNPs composites were prepared by UV radiation [57]. Graphene oxide (GO)-supported AgNPs nanocomposite was prepared via polyvinyl-pyrrolidone (PVP) and isopropanol (IPA)-assisted gamma irradiation [58].

Thermal synthesis is based on a thermal reduction of silver salt. A representative example is the thermal reduction of $\mathrm{AgNO}_{3}$ [59] in an environment of poly( $\mathrm{N}$-isopropylacryamide-co-2 -acrylamido-2-methylpropane sulfonic acid) (NIPAMSA) to form the hybrid hydrogels with incorporated AgNPs. 


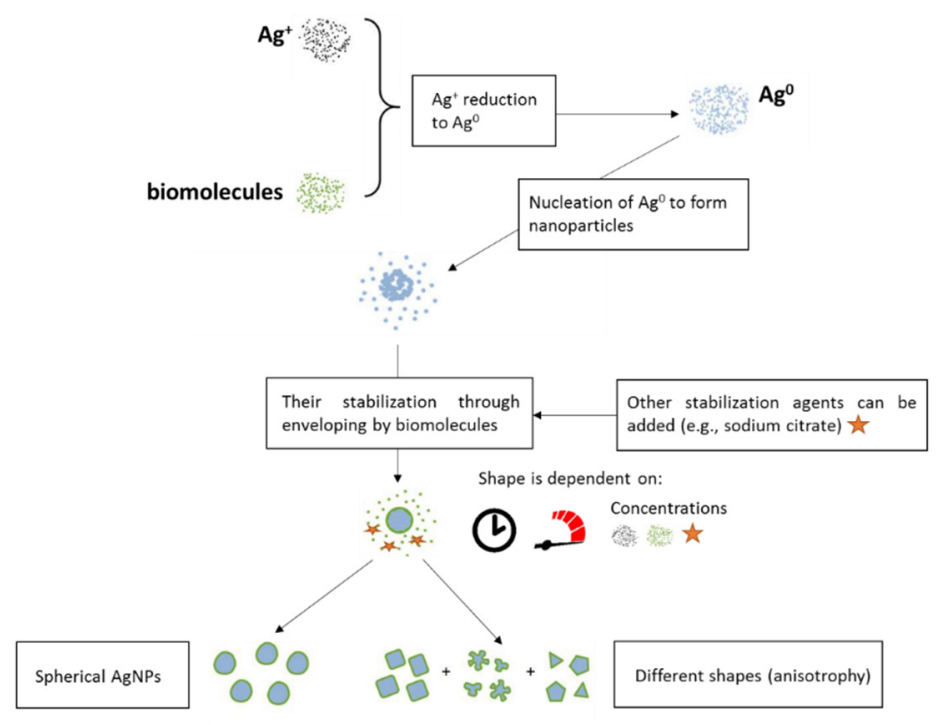

Figure 8. A model example of green synthesis of AgNPs. As mentioned in Figure 7, the green synthesis of AgNPs is based on using extracts from plants or fungi, which contain a giant spectrum of different oxidative and reductive agents. These molecules reduce silver ions $\left(\mathrm{Ag}^{+}\right)$to elementary silver $\left(\mathrm{Ag}^{0}\right)$. Compounds which influence the reduction and capping of originating AgNPs are, for example, proteins, alkaloids or polysaccharides. Different types of nanoparticles can be prepared depending on reaction conditions (metal concentration, extract concentration, length of synthesis, stabilization agents, etc.).

\section{AgNPs Immobilization into Membrane and Composite Material}

Membrane and composite material-immobilized nanoparticles can have a plethora of different functions (e.g., disinfection, catalytic activity). An example which can be mentioned as a composite material created by Liang et al. is a material based on a pre-treated egg-shell membrane with procyanidin to reduce silver ions into nanoparticles incorporated into the membrane structure. This membrane had catalytic activity consisting of the conversion of 4-nitrophenol to 4-aminophenol [60]. Silver ions reduced with ascorbic acid formed nanoparticles incorporated into polyethersulfone membranes and showed antibacterial activity against S. aureus, S. albus and E. coli when tested on bacterial plates [61]. Hanif et al. [62] used a non-toxic and environmentally friendly method based on tannic acid-mediated silver salt layer-by-layer in-situ reductions. This method was used for the preparation of a cellulose-AgNPs composite with uniform and controlled size and distribution of AgNPs for point-of-use water disinfection, which was tested successfully on E. coli bacteria. In the study published by Dong et al. [63], casein-coated AgNPs were embedded into acetate-cellulose membrane for control of biofouling. AgNPs effectively suppressed the growth of Serratia marcescens, and specifically, membranes with AgNPs displayed a decrease in microbial growth by $59-99 \%$ after this concentration was used [63]. Silver nanoparticles incorporated into the reverse osmosis membrane with a diameter of approximately $30 \mathrm{~nm}$ significantly reduced (by 64.6\%) Pseudomonas sp. biofilm formation after 14 days of continuous cultivation [64]. Another study which was proposed by Saraswathi et al. [65] was based on polydopamine-coated poly(ether imide) membranes with incorporated AgNPs. Membranes showed antibacterial activity against both Gram-negative and Gram-positive bacteria and facilitated the separation of toxic contaminants. In general, it can be concluded that AgNPs can be used in drinking water treatment and as a pseudo-enzymatic catalyst in the reaction. Additionally, AgNPs-incorporated membranes are used for wound treatment; representative examples are shown in Table 1. 
Table 1. AgNPs-membrane composites for wound treatment.

\begin{tabular}{|c|c|c|c|c|}
\hline AgNPs Preparation & AgNPs Size (nm) & Polymer Used & Incorporation Method & Main Result \\
\hline CHEMICAL METHOD $\left(\mathrm{NaBH}_{4}\right)$ & $5-14$ & $\mathrm{BC}$ & $\mathrm{BC}$ membrane was mixed with $\mathrm{AgNO}_{3}$ and reduced with $\mathrm{NaBH}_{4}$. & $\begin{array}{l}\text { Inhibition of S. aureus and E. coli growth on different sugar media (glucose, } \\
\text { sucrose, maltose) [66] }\end{array}$ \\
\hline CHEMICAL METHOD $\left(\mathrm{NaBH}_{4}\right)$ & 15 & Chitosan & $\begin{array}{l}\text { Chitosan was mixed with } \mathrm{AgNPs} \text { prepared by reduction of } \mathrm{AgNO}_{3} \\
\text { with } \mathrm{NaBH}_{4} \text { and the mixture was left to dry. }\end{array}$ & $\begin{array}{l}\text { AgNPs in chitosan wound dressing materials facilitate cell proliferation and } \\
\text { mitigate bacterial infection [67]. }\end{array}$ \\
\hline CHEMICAL METHOD (sodium citrate) & $10-30$ & PVP chitosan & $\begin{array}{l}\text { PVP and chitosan were mixed in a 1:1 ratio, then } \mathrm{AgNPs} \text { prepared by } \\
\text { reduction of } \mathrm{AgNO}_{3} \text { with sodium citrate were added, and afterward, } \\
\text { the mixture was dried for } 48 \mathrm{~h} \text {. }\end{array}$ & $\begin{array}{l}\text { Addition of } 0.001 \text { to } 0.01 \mathrm{mg} \mathrm{AgNPs} \text { to PVP-chitosan film significantly reduced the } \\
\text { growth of E. coli and S. aureus [68]. }\end{array}$ \\
\hline CHEMICAL METHOD (sodium citrate) & 5 & Chitin & $\begin{array}{l}\text { Chitin/nanosilver composite scaffolds were prepared by addition of } \\
\text { the nanosilver solution (prepared by reduction of } \mathrm{AgNO}_{3} \text { with } \\
\text { sodium citrate) to chitin hydrogel to obtain chitin/nanosilver } \\
\text { composite scaffolds. }\end{array}$ & 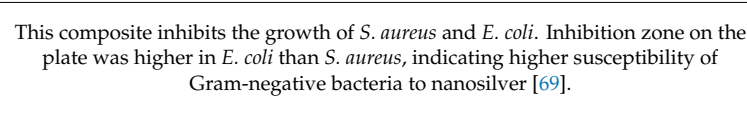 \\
\hline CHEMICAL METHOD $\left(\mathrm{NaBH}_{4}\right)$ & 3-17 & $\mathrm{BC}$ & $\begin{array}{l}\text { AgNPs were impregnated into BC fiber by immersing BC pellicles in } \\
\mathrm{AgNO}_{3} \text { for } 1 \mathrm{~h} \text {. The silver ion-saturated BC pellicles were reduced } \\
\text { with } \mathrm{NaBH}_{4} .\end{array}$ & $\begin{array}{l}\text { The growth inhibition ring of } E \text {. coli and S. aureus was } 2 \text { and } 3.5 \mathrm{~mm} \text {, respectively } \\
\text { No inhibition zone was observed with the pure BC as a control [70]. }\end{array}$ \\
\hline GREEN METHOD (egg white) & $8-32$ & KGM & KGM/AgNPs composite sponge & $\begin{array}{l}\text { Animal models showed that the KGM/AgNPs composite sponges effectively } \\
\text { accelerated wound healing, fibroblast growth promotion and wound } \\
\text { epithelialization on the rabbit model [71]. }\end{array}$ \\
\hline GREEN METHOD (Camelia sinensis) & $60-150$ & Chitosan and chitin & Film casting and dipping in $\mathrm{AgNO}_{3}$ solution & $\begin{array}{l}\text { Evaluation of nanofilms as a temporary biological wound dressing material for } \\
\text { rats had revealed good healing activity [72]. }\end{array}$ \\
\hline GREEN METHOD (chitosan) & 16 & Chitosan, PVA, CU & Film casting by evaporation & $\begin{array}{l}\text { AgNPs prepared from chitosan demonstrated significant effects against various } \\
\text { commmon pathogens (E.coli, S. aureus, P. aeruginosa, } C \text {. albicans) [73]. }\end{array}$ \\
\hline GREEN METHOD (cellulose from A. xylinum) & 50-150 & $B C$ & $\mathrm{AgNO}_{3}$ and $\mathrm{AgCl}$ reduced by $\mathrm{BC}$ and directly incorporated into $\mathrm{BC}$ & $\begin{array}{l}\text { Membranes exhibited high hydrophilic ability and strong antimicrobial activity } \\
\text { against S. aureus and E. coli [74]. }\end{array}$ \\
\hline IRRADIATION METHOD (gamma rays, ${ }^{60} \mathrm{Co}$ ) & $3-13$ & Chitin & $\begin{array}{l}\text { Gamma rays prepared AgNPs were mixed with chitin in } 5 \% \mathrm{LiCl} \text { and } \\
\text { DMA system. }\end{array}$ & $\begin{array}{l}\text { Bactericidal effect was significant }(p<0.01 \text { ) in the presence of chitin nanosilver } \\
\text { dressings, whereas the counts of bacteria progressively increased in the absence of } \\
\text { nanosilver dressings [75]. }\end{array}$ \\
\hline THERMAL METHOD (thermal reduction; $80^{\circ} \mathrm{C}$ ) & $10-30$ & Purchased BC & $\begin{array}{c}\text { Freeze-dried BC membrane impregnated with AgNPs (direct } \\
\text { incorporation) }\end{array}$ & $\begin{array}{l}\text { The thermally prepared AgNPs exhibited significant antibacterial activity, with } \\
\text { more than } 99 \% \text { reduction in S. aureus. Moreover, composites allowed attachment } \\
\text { and growth of epidermal cells with no cytotoxicity that emerged [76]. }\end{array}$ \\
\hline
\end{tabular}

Explanation of abbreviations: BC—bacterial cellulose; CU—curcumine; DMA—dimethylacetamide; KGM—konjac glucomannan; PVA—poly(vinylalcohol); PVP—poly(vinylpyrrolidone). 


\subsection{Chemical-Synthesized AgNPs Incorporated into Membranes and Composite Materials}

The bacterial cellulose (BC) membrane has been utilized as a template for the in-situ preparation of AgNPs through the chemical reduction method. The lyophilized cellulose membrane with AgNPs was placed on the E. coli or S. aureus grown on an agar plate and incubated at $37^{\circ} \mathrm{C}$ for $24 \mathrm{~h}$. The sample derived from maltose with a silver content of $1.06 \%$ realized $>99.99 \%$ killing ratio in the number of viable E. coli, when cultivated on maltose after a contact period of $18 \mathrm{~h}$. Therefore, $1.2 \mathrm{mg}$ of the silver-containing composite was sufficient to ensure no detectable growth of $E$. coli in $0.1 \mathrm{~mL}$ of medium with a bacteria concentration of around $108 \mathrm{CFU}$ (colony forming units)/mL [66].

Levi-Polyachenko et al. [67] prepared chitosan membrane by the solvent casting method and loaded it with a different concentration of hexagonal AgNPs synthesized through the chemical route to demonstrate the synergistic wound healing activity. The developed hexagonal AgNPs represented a new addition to the chitosan wound dressing materials, as they could facilitate cell proliferation, mitigate bacterial infection and generate mild hyperthermia for the delivery of small drug molecules [67].

Another chemical method for the synthesis of $\mathrm{AgNPs}$ using $\mathrm{AgNO}_{3}$ as a precursor was reported. The generated nanoparticles were loaded into casted poly(vinylpyrrolidone)-chitosan (PVP-chitosan) membrane. The PVP-chitosan-silver composite film found higher antibacterial activity than both chitosan and $\mathrm{AgNO}_{3}$ alone. The $\mathrm{L} 929$ cell lines were used for a cytotoxicity study and adult male albino rats (140-180 g) were selected for the in vivo wound healing study. The prepared film exhibited higher wound healing efficiency than the cotton gauge, $100 \%$ chitosan and other reported chitosan-based dressings [68].

The chemical reduction of $\mathrm{AgNO}_{3}$ resulted in the formation of AgNPs, which were loaded into the chitin hydrogel. These hydrogels were lyophilized to obtain the AgNPs-impregnated chitin membrane. These chitin-nanosilver composite scaffolds exhibited good blood clotting ability and were also found to be bactericidal against $S$. aureus and E. coli [69].

Maneerung et al. isolated BC [70] produced by Acetobacter xylinum. It was used as a template for the synthesis of AgNPs through the chemical method. The freeze-dried silver nanoparticle-impregnated BC exhibited strong antimicrobial activity against E. coli (Gram-negative) and S. aureus (Gram-positive) bacteria [70].

\subsection{Green-Synthesized AgNPs Incorporated into Membranes and Composite Materials}

A composite sponge was made using konjac glucomannan (KGM) as the polymer and loaded with AgNPs that were prepared through a green synthesis method using egg white as a reducing agent. Animal models showed that the KGM-AgNPs composite sponges had effectively accelerated the wound healing process. The histological findings showed that they promoted fibroblast growth and accelerated epithelialization [71].

The regenerated cellulose and chitosan were blended and made into a solution for film casting in the presence of $\mathrm{AgNO}_{3}$ as a precursor for AgNPs production through the green reduction method. The tea grains (Camellia sinensis) were used as a reducing as well as a capping agent for the NPs. Evaluation of the optimized composite film for temporary biological wound dressing materials on the experimental wounds of rats had revealed the significant wound healing of the experimentally treated wounds faster than the control wounds [72].

The solvent casting method was performed for the preparation of chitosan-polyvinyl alcohol (PVA)-curcumin (CU) composite membrane loaded with AgNPs. The $\mathrm{AgNO}_{3}$ solution precursor was added to the composite mixture, which led to the formation of AgNPs through the reduction of the precursor by chitosan and PVA. The antimicrobial and antifungal activity of the chitosan-PVA-AgNPs films demonstrated significant effects against E. coli, Pseudomonas, Staphylococcus, Micrococcus, C. albicans and $P$. aeruginosa. To improve the therapeutic efficiency further, CU was encapsulated along with chitosan-PVA-AgNPs nanocomposite films, which showed enormous growth inhibition of E. coli compared to plain CU and chitosan-PVA-AgNPs film alone [73]. 
The BC produced by Acetobacter xylinum was isolated and dipped in $\mathrm{AgNO}_{3}$ and $\mathrm{AgCl}$ solution to produce AgNPs. In-situ production of NPs was performed using the membrane as a template. The AgCl NPs-impregnated membrane exhibited high hydrophilic ability and strong antimicrobial activity against E. coli and S. aureus [74].

\subsection{Irradiation-Synthesized AgNPs Incorporated into Membranes and Composite Materials}

Chitin membranes loaded with AgNPs were prepared by the solvent casting method in the presence of $5 \% \mathrm{LiCl}$ and dimethylacetamide (DMA) solvent system. The NPs were prepared by the gamma irradiation method, using $\mathrm{AgNO}_{3}$ as the precursor. The chitin membranes were loaded with ascending concentrations of AgNPs from 30 to 100 ppm. The chitin membranes with 100 ppm AgNPs showed promising antimicrobial activity against common wound pathogens (P. aeruginosa and S. aureus) [75].

\subsection{Thermal-Synthesized AgNPs Incorporated in Membranes and Composite Materials}

In-situ preparation of AgNPs inside the BC membrane by thermal reduction at $80{ }^{\circ} \mathrm{C}$ was executed to obtain AgNPs-loaded BC scaffold. The results showed that AgNPs-BC exhibited significant antibacterial activity against S. aureus. Moreover, AgNPs-BC allowed attachment and growth of rat fibroblasts with low cytotoxicity. The fresh epidermal and dermis thicknesses of the skin treated with AgNPs-BC samples were 111 and $855 \mu \mathrm{m}$, respectively, which was significantly higher than 74 and $619 \mu \mathrm{m}$ for BC-treated groups and 57 and $473 \mu \mathrm{m}$ for untreated control wounds [76].

\section{Powdered AgNPs and Topical Application}

Powdered AgNPs are used for incorporation into different types of clothing and dressings. Representative examples are summarized in Table 2.

Table 2. Powdered AgNPs for wound treatment application.

\begin{tabular}{ccccc}
\hline $\begin{array}{c}\text { Method of AgNPs } \\
\text { Preparation }\end{array}$ & AgNPs Size (nm) & Material Used & Incorporation Method & Main Result \\
\hline $\begin{array}{c}\text { CHEMICAL } \\
\text { METHOD (alkali } \\
\text { solution of starch) }\end{array}$ & $22-24$ & cotton fabrics & $\begin{array}{c}\text { Pressure incorporation of } \\
\text { AgNPs to cotton fabrics }\end{array}$ & $\begin{array}{c}\text { 13- and 10-mm inhibition zones for S. aureus and E. coli } \\
\text { were obtained, when cotton fabrics with 250 ppm } \\
\text { AgNPs were used [77]. }\end{array}$ \\
\hline $\begin{array}{c}\text { CHEMICAL } \\
\text { METHOD (NaBH } 4)\end{array}$ & $4-24$ & dressing material & $\begin{array}{c}\text { AgNPs-coated } \\
\text { dressing material }\end{array}$ & $\begin{array}{c}\text { AgNPs showed antimicrobial properties, reduction in } \\
\text { wound inflammation and modulation of fibrogenic } \\
\text { cytokines [78]. }\end{array}$ \\
\hline $\begin{array}{c}\text { GREEN METHOD } \\
\text { (Fusarium oxysporum })\end{array}$ & 2 & cotton fabrics & $\begin{array}{c}\text { Incorporation to } \\
\text { cotton fabrics }\end{array}$ & $\begin{array}{c}\text { AgNPs-impregnated fabrics showed a 99.9\% reduction } \\
\text { of S. aureus growth [79]. }\end{array}$ \\
\hline $\begin{array}{c}\text { GREEN METHOD } \\
\text { (Aspergillus niger })\end{array}$ & $200-800$ & $\begin{array}{c}\text { AgNPs-incorporated } \\
\text { wound dressings }\end{array}$ & $\begin{array}{c}\text { AgNPs-coated } \\
\text { dressing material }\end{array}$ & $\begin{array}{c}\text { AgNPs synthesized from Aspergillus niger possess } \\
\text { effective wound healing activity when compared with } \\
\text { AgNO }\end{array}$ \\
\hline
\end{tabular}

\subsection{Chemical-Synthesized Powdered AgNPs and Topical Application}

The powdered AgNPs were successfully prepared via the addition of $\mathrm{AgNO}_{3}$ to alkali dissolved starch followed by precipitation with ethanol. AgNPs aqueous suspensions were prepared from powder AgNPs by dispersion and dilution with water. The cotton fabrics were impregnated with AgNPs by dipping in the solution with various concentrations. The results of potent healing using fabrics treated with 250 ppm AgNPs were similar to the Dermazin cream. Moreover, the anti-inflammatory effect of AgNPs was nearly equivalent to a $20-\mathrm{mL}$ dose of the reference indomethacin drug [77].

The wound dressing materials coated with chemically synthesized AgNPs were tested for their antibacterial activity. Rapid healing and improved cosmetic appearance were observed in a dose-dependent manner. Furthermore, through quantitative PCR, immunohistochemistry and proteomic studies, the positive effects exerted by AgNPs by their antimicrobial properties, reduction in wound inflammation and modulation of fibrogenic cytokines were demonstrated [78]. 


\subsection{Green-Synthesized Powdered AgNPs and Topical Application}

Duran et al. synthesized AgNPs using Fusarium oxysporum. AgNPs were loaded inside the clothes and tested for their antibacterial activity against S. aureus. AgNPs demonstrated a $99 \%$ reduction in bacterial counts [79].

Sundaramoorthi et al. prepared AgNPs from Aspergillus niger using $\mathrm{AgNO}_{3}$ as a precursor. AgNPs incorporated into wound dressings had antibacterial activity and formed inhibition zones: $15 \mathrm{~mm}$ for S. aureus, $11 \mathrm{~mm}$ for B. subtilis, $10 \mathrm{~mm}$ for E. coli and $14 \mathrm{~mm}$ for P. aeruginosa [80].

\section{Nanofibers}

Nanofibers as materials can be used as a platform in Raman spectroscopy [81], in immunoanalysis [82], for air filtration [83] and as a pseudo-enzyme [84]. As can be seen, the AgNPs, besides their important wound treatment activity, which is summarized in Table 3 below, can be used also for disinfection and catalytic purposes.

Table 3. AgNPs nanofibers for wound treatment.

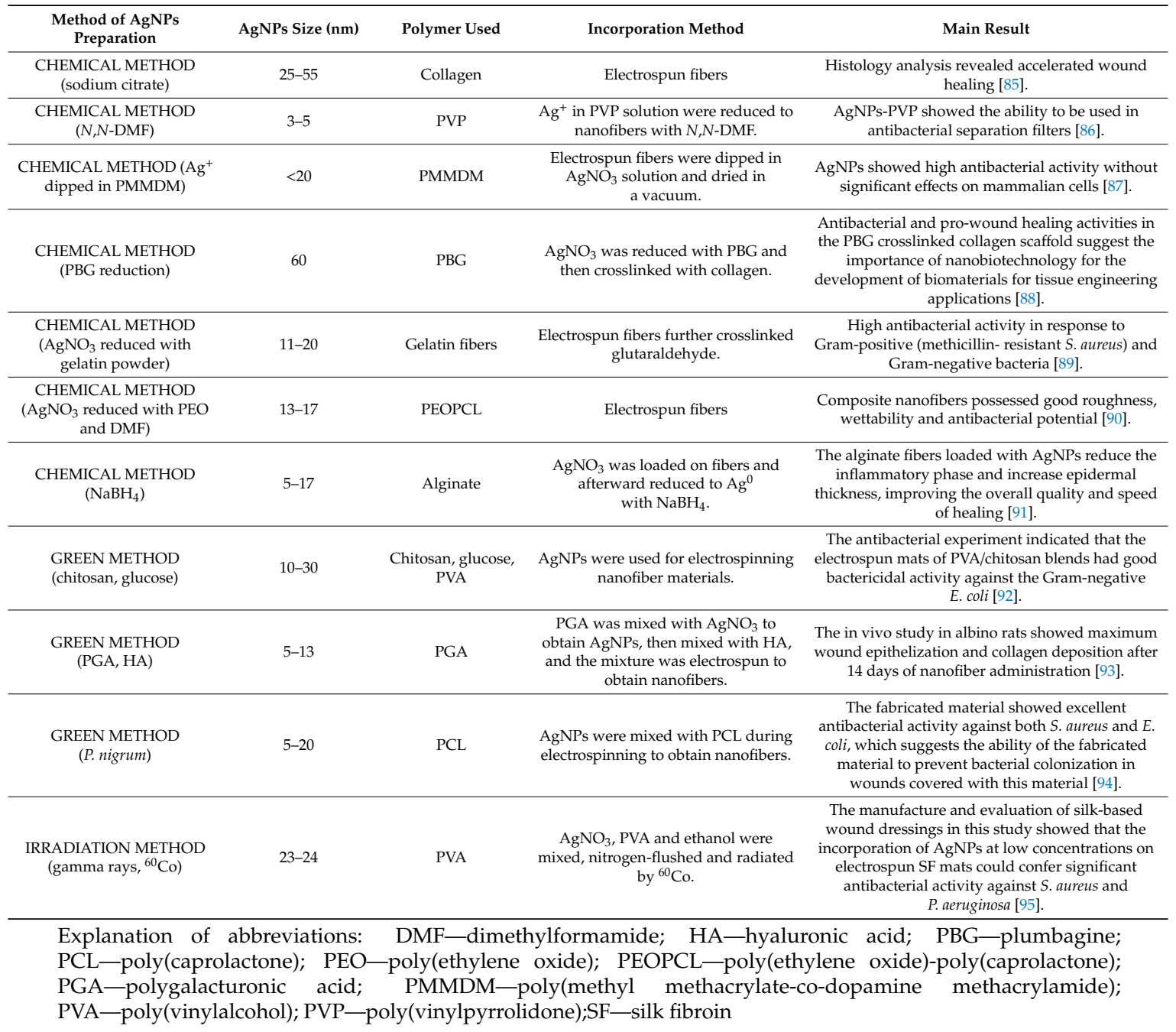

\subsection{Chemical Synthesis of AgNP-Containing Nanofibers}

The chemically synthesized AgNPs were added to the electrospinning solution containing collagen to obtain the nanofibers. The in-vivo study proved that the rate of wound healing of the composite nanofiber mats was accelerated compared with plain collagen nanofibers. Histology analysis revealed 
accelerated re-epithelization, collagen production and better wound contraction with AgNPs composite collagen nanofibers [85].

The PVP nanofibers loaded with AgNPs that were reduced from precursor by $\mathrm{N}, \mathrm{N}$-dimethylformamide (DMF) were reported. The PVP-containing AgNPs could be used to introduce the nanoparticles into any other polymer nanofibers that are miscible with PVP. The PVA nanofiber mats were strong enough to act as antimicrobial separation filters [86].

An electrospun fiber made of poly(methyl methacrylate-co-dopamine methacrylamide) (PMMDM) was dipped into the $\mathrm{AgNO}_{3}$ solution for on-surface synthesis of AgNPs. The PMMDM-AgNP composite nanofibers containing $1 \%$ NPs achieved desirable antibacterial activity against both Gram-negative and Gram-positive bacteria, while not significantly affecting the viability of mammalian cells. The product was also observed with a rapid release of the AgNPs within $24 \mathrm{~h}$, followed by a sustained release for 5 days thereafter [87].

The collagen fibrils were isolated from the tendons of Wistar rats and allowed to crosslink with plumbagin (PBG)-caged AgNPs that were prepared using the chemical oxido-reduction method, using $\mathrm{PBG}$ and $\mathrm{AgNO}_{3}$ as precursors. Crosslinking of collagen with $\mathrm{PBG}$ resulted in a uniform alignment of collagen fibrils to form orderly aligned porous structured scaffolds with potent antibacterial activity and enhanced ability to promote cell proliferation and wound healing [88].

The gelatin nanofibers prepared by the electrospinning technique were incorporated with AgNPs that were prepared in-situ by the chemical reduction method. The fibers were further crosslinked with glutaraldehyde to enhance mechanical stability. The antibacterial activity of the fibers was greatest against P. aeruginosa, S. aureus, E. coli and methicillin-resistant S. aureus [89].

The electrospun nanofibers of poly(ethylene oxide)-poly(caprolactone) (PEOPCL) blend were prepared in dimethylformamide solvent. The precursor $\mathrm{AgNO}_{3}$ was added to the electrospinning solution, which was chemically reduced by DMF and poly(ethylene oxide) (PEO). In addition, the PEO acted as a stabilizer for the formation of NPs. The composite nanofibers possessed antibacterial potential against antibiotic-resistant E. coli [90].

A wet spinning technique was carried out in the $\mathrm{CaCl}_{2}$ precipitation bath for the preparation of alginate fibers. The chemically reduced AgNPs solution was mixed with a spinning solution, which resulted in AgNPs-incorporated alginate fibers. AgNPs-loaded fibers could be easily applied in a wound healing paradigm, which could promote the repair process through the promotion of fibroblast migration to the wound area, reduction of the inflammatory phase and an increase in epidermal thickness in the repaired wound area, thereby improving the overall quality and speed of healing [91].

\subsection{Green Synthesis of AgNPs-Containing Nanofibers}

A green method for the synthesis of AgNPs was reported through the electrospinning technique in the presence of chitosan as a reducing agent along with PVA to obtain nanofibers. The results showed the superior qualities of the fibers and synergistic antibacterial effects by the combination of chitosan with AgNPs [92].

Very recently, El-Aassar et al. published a methodology to obtain silver-containing nanofibers by using polygalacturonic and hyaluronic acid. Successful AgNPs synthesis by PGA was verified by UV-vis spectral maxima ranging between 410 and $415 \mathrm{~nm}$ and a transmission electron microscopy image of $8.6 \mathrm{~nm}$ average particulate diameter. AgNPs components of (Ag-PGA/HA)-PVA nanofiber exhibited robust zone inhibition antibacterial activity against both Gram-positive and Gram-negative bacteria [93].

Another green synthesis method was also reported for developing AgNPs using P. nigrum leaf extract. The NPs solution was mixed with polycaprolactone (PCL) solution during electrospinning to obtain the nanofibers. The fabricated material showed excellent antibacterial activity against both S. aureus and E. coli, which also confirmed the ability to prevent bacterial colonization in wounds covered with this composed material [94]. 


\subsection{Irradiation Synthesis of Silver Nanofibers}

Nanofibers of silk fibroin were prepared using an electrospinning technique and loaded with AgNPs synthesized from the $\mathrm{AgNO}_{3}$ precursor using the gamma irradiation method. AgNPs-coated nanofibers effectively inhibited the growth of $S$. aureus and P. aeruginosa when the coating solution containing colloidal AgNPs was $4 \mathrm{mM}$ or equivalent to $50.4 \mathrm{ng} / \mathrm{cm}^{2}$ of adsorbed AgNPs [95].

\section{AgNPs-Hydrogels}

AgNPs incorporated in poly( $\mathrm{N}$-iospropylacryamide-co-acrylamido-2-methylpropane sulfonic acid) (NIPAMSA) cryogel were used for the reduction of 4-nitrophenol to 4-aminophenol [59]. AgNPs/starch/PEG/PAA hydrogel was created by Saberi et al. for $\mathrm{Hg}^{2+}$ removal. The maximum adsorption capacity of $\mathrm{Hg}^{2+}$ ions for hydrogel was found to be $158.21 \mathrm{mg} / \mathrm{g}$ and $182.53 \mathrm{mg} / \mathrm{g}$ in $\mathrm{pH} 7$ and 6 in aqueous solutions, respectively [96]. Similarly, Dil and Sadeghi created nanosilver/gelatin/PAA hydrogel for $\mathrm{Cu}^{2+}$ removal. The absorption capacity was $147.10 \mathrm{mg} / \mathrm{g}$ in pH 5.5 for $40 \mathrm{~min}$, measured with the atomic absorption spectroscopy technique [97]. As seen, AgNPs-hydrogels, besides their wound applications, are used for metal removal and catalytic activity. Their usage for wound treatment is shown in Table 4.

Table 4. AgNPs hydrogels for wound treatment.

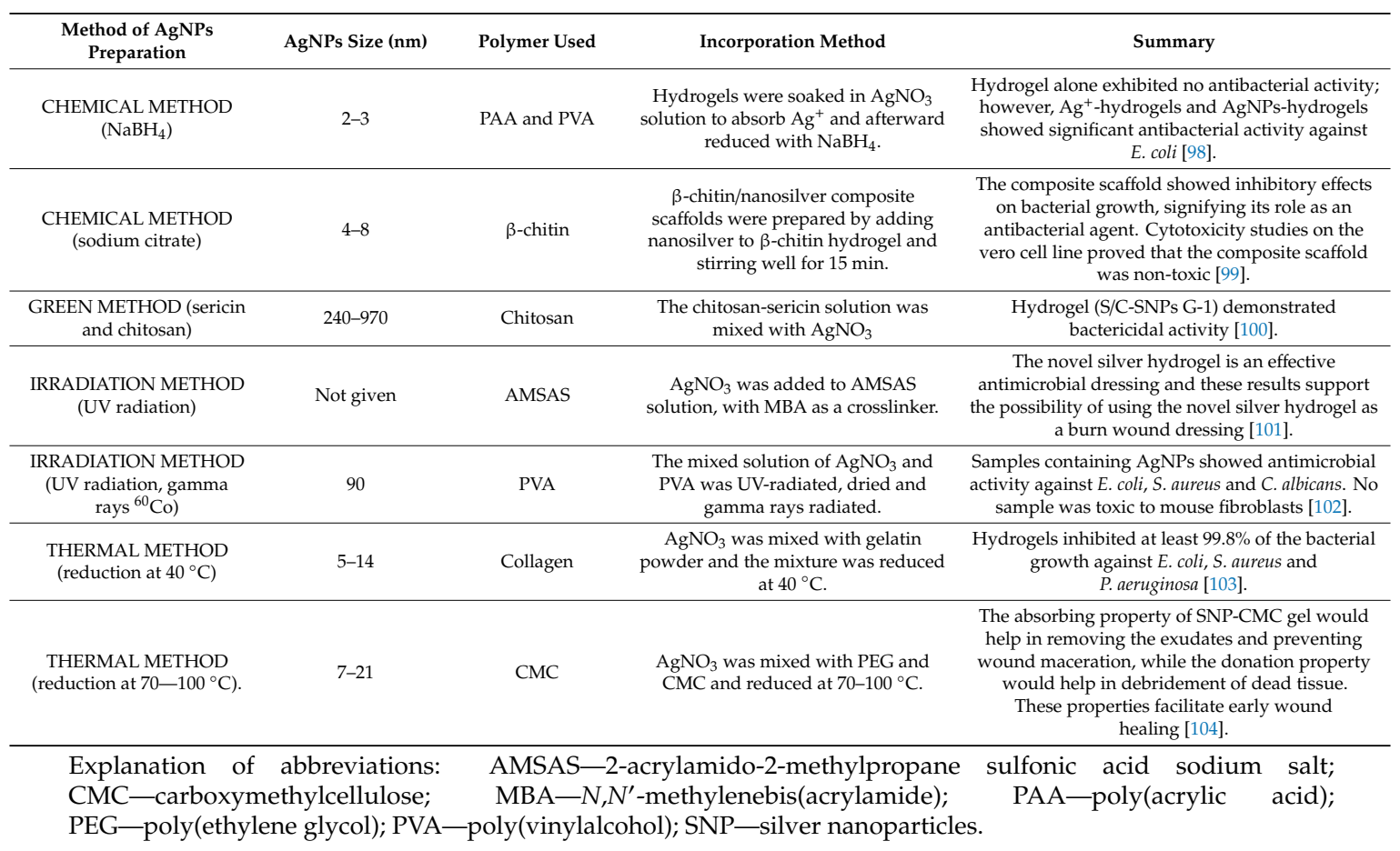

\subsection{Chemical Synthesis of AgNPs-Containing Hydrogels}

The hydrogel made of polyacrylamide/poly(vinyl alcohol) was used as a template to produce AgNPs through the chemical route. The engineered hydrogel-AgNPs exhibit higher activity on E. coli compared to AgNPs alone [98].

Using $\beta$-chitin as the starting material, the hydrogel was prepared and loaded with chemically synthesized AgNPs. The prepared $\beta$-chitin/nanosilver composite scaffolds exhibited significant bactericidal activity against $E$. coli and $S$. aureus and showed good blood-clotting ability. Cell attachment studies using vero (epithelial) cells showed better adherence of the cells on the scaffolds [99]. 


\subsection{Green Synthesis of AgNPs-Containing Hydrogels}

A hydrogel made of carbopol was loaded with in-situ prepared AgNPs, using sericin and chitosan as capping and reducing agents, respectively. The antimicrobial activity and wound healing activity of the optimized hydrogel demonstrated higher bactericidal activity and wound closure, as supported by results of histopathology [100].

\subsection{Irradiation Synthesis of AgNPs-Containing Hydrogels}

A novel wound dressing material was prepared using 2-acrylamido-2-methylpropane sulfonic acid sodium salt (AMSAS) hydrogel loaded with AgNPs. The silver nitrate solution was added to the AMSAS solution and the NPs synthesis was initiated through gamma irradiation. This novel silver hydrogel showed excellent antimicrobial activity. A hydrogel made of AMSAS was prepared and loaded with $\mathrm{AgNO}_{3}$ solution and the reaction mixture was irradiated with UV radiation for the formation of AgNPs. The antibacterial activity of the hydrogels against common burn pathogens was studied and the results showed that $5 \mathrm{mM}$ AgNPs-loaded hydrogel had the greatest inhibitory activity [101].

The PVA solution mixed with the $\mathrm{AgNO}_{3}$ solution was gamma-irradiated for the reduction process of the precursor and then made into hydrogels. The hydrogels were dried in vacuum at $40{ }^{\circ} \mathrm{C}$. PVA-Ag samples were non-toxic and presented antimicrobial activity, confirming that $0.25 \%$ $\mathrm{AgNO}_{3}$ concentration was enough to establish a potential antimicrobial effect. The samples also presented suitable mechanical and swelling properties in all media, representative for potential burn site applications [102].

\subsection{Thermal Synthesis of AgNPs-Containing Hydrogels}

Gelatin solution was mixed with the $\mathrm{AgNO}_{3}$ solution, wherein the precursor was reduced at $40{ }^{\circ} \mathrm{C}$. Furthermore, hydrogels were prepared from the same, which were effective against $S$. aureus, E. coli and P. aeruginosa, with at least $99.7 \%$ bacterial growth inhibition. The hydrogels containing $\mathrm{AgNO}_{3}$ at 0.75 and $1.0 \mathrm{wt} \%$ were not detrimental to the skin cells that had been cultured directly on them [103].

The in-situ preparation of AgNPs inside carboxymethylcellulose (CMC) gel was carried out. The antimicrobial activity studies showed that CMC-SNP containing 50 ppm of AgNPs was effective against the growth of both Gram-negative and Gram-positive strains including methicillin-resistant S. aureus. These results indicated that the reported nanoparticles could be an ideal option for the treatment of deep infected wounds [104].

In total, 28 publications with mention of the tested microorganisms (Table 5) were searched to determine which bacteria and fungi are used for testing materials for wound dressings (publications from Table 1, Table 2, Table 3, Table 4 were used, except $[67,72,78,86,105]$, where no microorganisms but eukaryotic cells were tested). As seen in Table 5, S. aureus is the most favored model as a Gram-positive bacterium because it is a high-priority pathogen [106]. Very favored models for wound testing are also Gram-positive E. coli and P. aeruginosa. Besides bacteria, fungi models are also tested (C. albicans).

Table 5. Frequency of tested bacteria and fungi for wound treatment.

\begin{tabular}{cccc}
\hline Cell Species & AA & RA (\%) & References \\
\hline S. aureus * & 24 & 85.7 & {$[66,68-71,73-77,79,80,85,87,89,92-94,99-104]$} \\
E. coli & 22 & 78.6 & {$[66,68-71,73,74,76,77,79,80,87-90,93,94,98,99,102-104]$} \\
Micrococcus & 1 & 3.6 & {$[73]$} \\
P. aeruginosa & 9 & 32.1 & {$[73,75,76,80,85,87,89,101,103]$} \\
C. albicans & 4 & 14.3 & {$[73,77,101,102]$} \\
Enterococcus & 1 & 3.6 & {$[101]$} \\
B. subtilis & 3 & 10.7 & {$[80,88,93]$} \\
A. baumannii & 1 & 3.6 & {$[101]$} \\
\hline * including methicillin-resistant S. aureus, AA-absolute abundance, RA-relative abundance.
\end{tabular}




\section{Safety of AgNPs in Wound Dressing Applications}

The question of the potential toxicity of AgNPs is widely discussed. Nanomaterials can easily pass through cell membranes and adversely affect human health [107]. In mouse models, they passed through the blood-brain and blood-testis barriers [108]. AgNPs in higher concentrations $(>44.0 \mu \mathrm{g} / \mathrm{mL})$ are necrotic to cells, resulting in cell membrane rupture [107]. After their passing through the blood-testis barrier, AgNPs are deposited in the testes and can have adverse effects on sperm cells [109]. They have also been shown to damage other cells such as the brain [110], liver [111] and stem cells [112]. However, the findings of many authors indicated that the use of AgNPs as a topical antibacterial agent is safe. The AgNPs-loaded hydrogel is considered an excellent wound dressing [113]. If used in reasonable quantities, silver metal and silver dressings have no negative effects on human health [114,115]. For example, Kokura et al. [116] studied the permeability of AgNPs in human skin and their cytotoxicity in human HaCaT (a spontaneously immortalized human keratinocyte line) keratinocytes under ultraviolet B (UVB) irradiation. Based on a transcutaneous passage assay using human skin, AgNPs did not penetrate healthy intact human skin. AgNPs showed no effect on keratinocytes and did not increase UVB-induced cell death. The efficacy of AgNPs increases at low concentrations. AgNPs do not easily penetrate the skin barrier and have no detrimental effects on keratinocytes [116]. Thus, AgNPs possess the outstanding potential for use in wound dressing applications.

In addition, NPs are generally considered a promising replacement for antibiotics due to their bactericidal activity against a large number of pathogens and the non-induction of microbial resistance [117]. AgNPs, in particular, have received a great deal of attention from scientists due to their inhibitory effect on around 650 microbe species and antibiotic-resistant bacteria [118]. AgNPs inhibit bacterial reproduction by denaturing bacterial DNA, leading to the alteration and subsequently the death of the bacterial cell [119]. Moreover, AgNPs can be an appropriate therapeutic agent or prophylactic because they prevent the colonization of the wound by antibiotic-resistant bacteria and other microbes that impede wound healing [120]. Based on using human keratinocytes and dermal fibroblasts, AgNPs significantly reduced levels of inflammatory cytokines and promoted healing [121]. In vitro cell culture tests exhibited no cytotoxicity in the hydrogel containing AgNPs and non-adherent character to dermal fibroblasts [122]. Compared with conventional topical agents, AgNPs can both effectively prevent wound infections and improve the healing process of injured tissues. AgNPs-coated wound dressings possess considerable antibacterial activity and repair tissues faster and more efficiently [123]. Application of silver modified nanoporous silica carriers loaded with sulfadiazine instead of silver sulfadiazine could overcome the poor aqueous solubility of silver sulfadiazine which limits its antibacterial effect [124].

On the contrary, some authors are convinced of the risks of using AgNPs. Some cases where argyria appeared after treatment of burn wounds with dressings containing nanocrystalline silver were reported $[125,126]$. The use of these dressings caused the deposition of the silver particles into the mid and deep dermis [125]. For silver itself, it was found that this metal had a concentration-dependent cytotoxic effect on human dermal fibroblast cells [127]. However, thanks to the development of nanotechnology, its minimum inhibitory concentration, as well as toxicity to normal human cells, was reduced [128] and a number of brands of wound dressings containing silver have been accepted by the U.S. Food and Drug Administration [100]. On the other hand, Burd et al. [129] demonstrated that some commercial silver-based dressings exhibited cytotoxic effects on cultured keratinocytes and fibroblasts.

\section{Conclusions}

Nanomaterials nowadays represent a very promising way to eliminate bacterial, fungal and viral infections. Besides their antibiotic, antifungal and antiviral effects, they are used as catalysts, bioremediation elements and pseudo-enzymes. This review represents successful results of the nanotechnology field in the very last years. Acute and chronic wounds are problematic to heal and are 
often underestimated by people. The types of treatment were divided based on article information into four categories: membranes, powdered, nanofibers and hydrogels, prepared by different types of synthesis. It can be concluded that the chemical method of synthesizing NPs can obtain NPs with uniformity and reproducibility of preparation. However, a growing supply of lowering of environment pollution is not in consensus with the use of this type of synthesis. Green synthesis is much more environmentally and user friendly because it uses a natural source of reduction agents. A wide spectrum of different types of NPs can be obtained. It is necessary to mention that optimization of the production of uniform green-synthesized NPs can take a long time because slight, unwitting changes in laboratory protocol can lead to the production of NPs with completely different chemical and physical properties. Furthermore, the detailed characterization of an extract of plant or fungus is needed. Irradiation synthesis of nanoparticles shows an interesting way to produce unique, unrepeatable NPs, which can be considered as the main advantage. The main disadvantages are the complicated legislature connected with work with radiation sources and increase the risk of harm to health. Thermal synthesis is based on artificial or natural chemicals as reducing agents connected with increased temperature. In its essence, it is a combination of green and chemical synthesis methods, where the higher temperature is the main element of reduction power. Potential advantages and disadvantages ensue from other components used in thermal synthesis. Despite a plethora of different publications in recent years, it is still necessary to find new polymers and new types of synthesis of (not only) AgNPs, because of the growing bacterial resistance to metal NPs. It is important mainly not to forget to conduct valid tests on eukaryotic cells to determine how to achieve the best effect against prokaryotic cells and at the same time ensure no harmful effect against eukaryotic cells. Suitable models can be keratinocytes and fibroblasts, which are also mentioned as models in this publication.

Author Contributions: V.H.B.N., P.D.K., R.D.D. and H.V.N. found appropriate articles for writing this review and critically revised manuscript. D.K. categorized articles into different categories, created the basic structure for the review and produced images of wound treatment with silver nanomaterials and summarization of antimicrobial wound dressings with nanomaterials. B.R.-N. created the image representing the effect of AgNPs on the single bacterial cell and critically revised manuscript. M.K., C.F., A.F. and J.S. critically revised manuscript. B.H. corrected mistakes connected with formal adjustment of the manuscript, participated in writing the text and suggested figure improvements. D.B. created the logical structure of the manuscript, drew the flowchart of choice of appropriate articles for review, improved quality of text and figures and wrote introduction and chapters about the different synthesis of nanoparticles. R.K. participated in writing the manuscript, critically revised the manuscript and produced images of model example of green synthesis of AgNPs and the process of preparation of AgNPs. All authors have read and agreed to the published version of the manuscript.

Funding: The work was carried out with the support of the H2020 CA COST Action CA15114, INTER-COST LTC18002.

Acknowledgments: The international collaboration project of the European Technology Platform for Nanomedicine is gratefully acknowledged. Carlos Fernandez would like to express his gratitude to PALS for its support. Vedha Hari B Narayanan thanks DST-SERB, Government of India for providing research funding through the Early Career Research Award (ECR/2016/001856). The authors also thank Vít Skoták, who helped with creative figure suggestions.

Conflicts of Interest: The authors declare no conflict of interest.

\section{Abbreviations}

$\begin{array}{ll}\text { AgNPs } & \text { silver nanoparticles } \\ \text { AMSAS } & \text { 2-acrylamido-2-methylpropane sulfonic acid sodium salt } \\ \text { BC } & \text { bacterial cellulose } \\ \text { CMC } & \text { carboxymethylcellulose } \\ \text { CU } & \text { curcumine } \\ \text { DMA } & \text { dimethylacetamide } \\ \text { DMF } & \text { dimethylformamide } \\ \text { GO } & \text { graphene oxide } \\ \text { HA } & \text { hyaluronic acid }\end{array}$




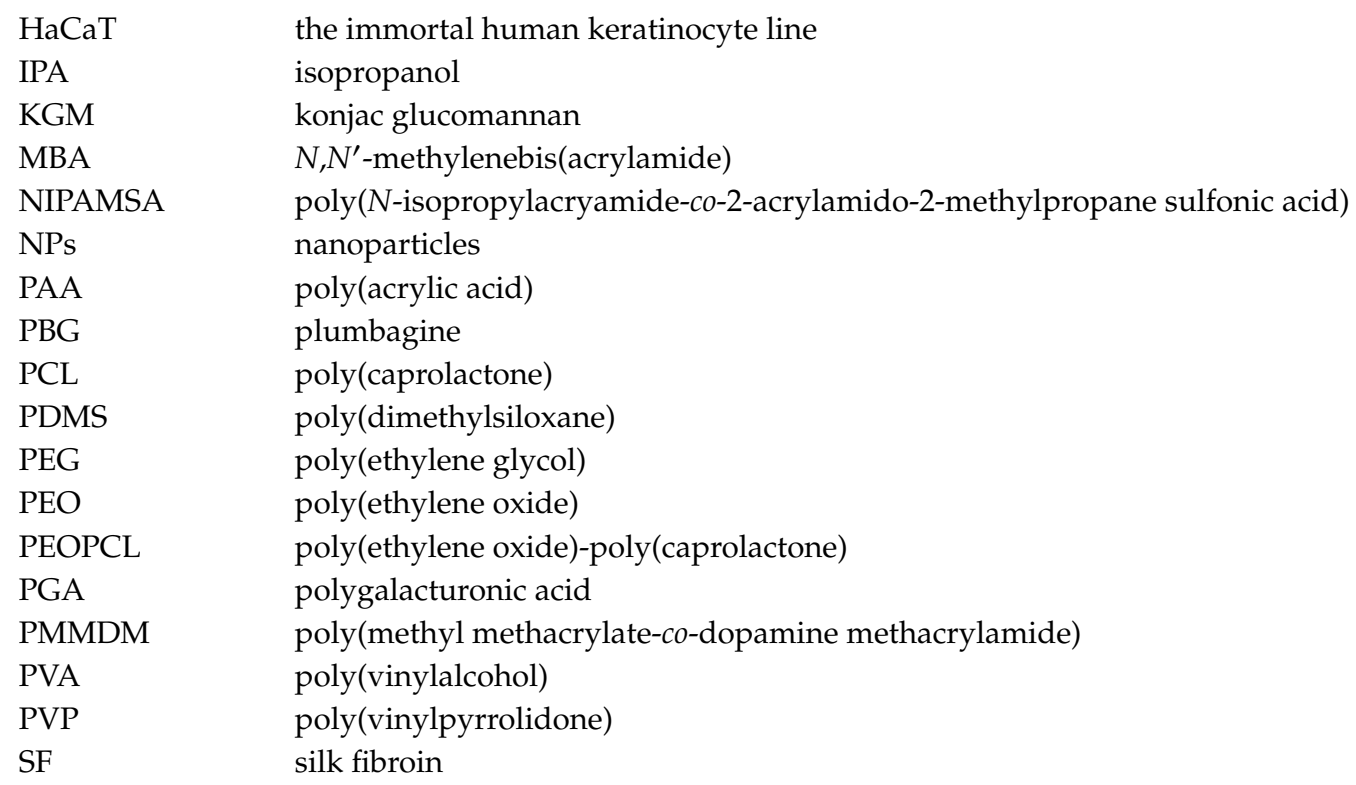

\section{References}

1. Augustine, R.; Zahid, A.A.; Hasan, A.; Wang, M.; Webster, T.J. CTGF loaded electrospun dual porous core-shell membrane for diabetic wound healing. Int. J. Nanomed. 2019, 14, 8573-8588. [CrossRef]

2. Garcia-Villen, F.; Faccendini, A.; Aguzzi, C.; Cerezo, P.; Bonferoni, M.C.; Rossi, S.; Grisoli, P.; Ruggeri, M.; Ferrari, F.; Sandri, G.; et al. Montmorillonite-Norfloxacin nanocomposite intended for healing of infected wounds. Int. J. Nanomed. 2019, 14, 5051-5060. [CrossRef]

3. Pang, S.C.; Gao, Y.; Wang, F.B.; Wang, Y.Y.; Cao, M.X.; Zhang, W.J.; Liang, Y.; Song, M.Y.; Jiang, G.B. Toxicity of silver nanoparticles on wound healing: A case study of zebrafish fin regeneration model. Sci. Total Environ. 2020, 717, 10. [CrossRef]

4. Azeredo, J.; Azevedo, N.F.; Briandet, R.; Cerca, N.; Coenye, T.; Costa, A.R.; Desvaux, M.; Di Bonaventura, G.; Hébraud, M.; Jaglic, Z.; et al. Critical review on biofilm methods. Crit. Rev. Microbiol. 2017, 43, 313-351. [CrossRef]

5. Percival, S.L.; Salisbury, A.M.; Chen, R. Silver, biofilms and wounds: Resistance revisited. Crit. Rev. Microbiol. 2019, 45, 223-237. [CrossRef]

6. Kim, J.H.; Yang, B.; Tedesco, A.; Lebig, E.G.D.; Ruegger, P.M.; Xu, K.R.; Borneman, J.; Martins-Green, M. High levels of oxidative stress and skin microbiome are critical for initiation and development of chronic wounds in diabetic mice. Sci. Rep. 2019, 9, 16. [CrossRef]

7. Theuretzbacher, U.; Bush, K.; Harbarth, S.; Paul, M.; Rex, J.H.; Tacconelli, E.; Thwaites, G.E. Critical analysis of antibacterial agents in clinical development. Nat. Rev. Microbiol. 2020, 18, 286-298. [CrossRef]

8. Banerjee, S.; Vishakha, K.; Das, S.; Dutta, M.; Mukherjee, D.; Mondal, J.; Mondal, S.; Ganguli, A. Antibacterial, anti-biofilm activity and mechanism of action of pancreatin doped zinc oxide nanoparticles against methicillin resistant Staphylococcus Aureus. Colloid Surf. B Biointerfaces 2020, 190, 11. [CrossRef]

9. Kim, D.; Lee, H.; Yoon, E.J.; Hong, J.S.; Shin, J.H.; Uh, Y.; Shin, K.S.; Shin, J.H.; Kim, Y.A.; Park, Y.S.; et al. Prospective observational study of the clinical prognoses of patients with bloodstream infections caused by ampicillin-susceptible but penicillin-resistant Enterococcus faecalis. Antimicrob. Agents Chemother. 2019, 63, 11. [CrossRef]

10. Kardan-Yamchi, J.; Kazemian, H.; Battaglia, S.; Abtahi, H.; Foroushani, A.R.; Hamzelou, G.; Cirillo, D.M.; Ghodousi, A.; Feizabadi, M.M. Whole genome sequencing results associated with minimum inhibitory concentrations of 14 anti-tuberculosis drugs among rifampicin-resistant isolates of mycobacterium tuberculosis from Iran. J. Clin. Med. 2020, 9, 465. [CrossRef]

11. Natan, M.; Banin, E. From Nano to Micro: Using nanotechnology to combat microorganisms and their multidrug resistance. FEMS Microbiol. Rev. 2017, 41, 302-322. [CrossRef] 
12. Shehabeldine, A.M.; Ashour, R.M.; Okba, M.M.; Saber, F.R. Callistemon citrinus bioactive metabolites as new inhibitors of methicillin-resistant Staphylococcus aureus biofilm formation. J. Ethnopharmacol. 2020, 254, 12. [CrossRef]

13. Halawani, E.M.; Hassan, A.M.; El-Rab, S. Nanoformulation of biogenic cefotaxime-conjugated-silver nanoparticles for enhanced antibacterial efficacy against multidrug-resistant bacteria and anticancer studies. Int. J. Nanomed. 2020, 15, 1889-1901. [CrossRef]

14. Hamida, R.S.; Abdelmeguid, N.E.; Ali, M.A.; Bin-Meferij, M.M.; Khalil, M.I. Synthesis of silver nanoparticles using a novel cyanobacteria desertifilum sp. extract: Their antibacterial and cytotoxicity effects. Int. J. Nanomed. 2020, 15, 49-63. [CrossRef]

15. Lomeli-Marroquin, D.; Cruz, D.M.; Nieto-Arguello, A.; Crua, A.V.; Chen, J.J.; Torres-Castro, A.; Webster, T.J.; Cholula-Diaz, J.L. Starch-Mediated synthesis of mono-and bimetallic silver/gold nanoparticles as antimicrobial and anticancer agents. Int. J. Nanomed. 2019, 14, 2171-2189. [CrossRef]

16. López, R.A.; Bartomeu, G.C.; Navarro, G.S.M.; Webster, T. Novel Silver-Platinum Nanoparticles for anticancer and antimicrobial applications. Int. J. Nanomed. 2020, 15, 169-179. [CrossRef]

17. Yuan, Y.C.; Zhu, H.; Wang, X.D.; Cui, D.Z.; Gao, Z.H.; Su, D.; Zhao, J.; Chen, O. Cu-Catalyzed synthesis of CdZnSe-CdZnS alloy quantum dots with highly tunable emission. Chem. Mat. 2019, 31, 2635-2643. [CrossRef]

18. Toy, R.; Peiris, P.M.; Ghaghada, K.B.; Karathanasis, E. Shaping cancer nanomedicine: The effect of particle shape on the in vivo journey of nanoparticles. Nanomedicine 2014, 9, 121-134. [CrossRef]

19. Poizot, P.; Laruelle, S.; Grugeon, S.; Dupont, L.; Tarascon, J.M. Nano-Sized transition-metaloxides as negative-electrode materials for lithium-ion batteries. Nature 2000, 407, 496-499. [CrossRef]

20. Nel, A.E.; Madler, L.; Velegol, D.; Xia, T.; Hoek, E.M.V.; Somasundaran, P.; Klaessig, F.; Castranova, V.; Thompson, M. Understanding biophysicochemical interactions at the nano-bio interface. Nat. Mater. 2009, 8, 543-557. [CrossRef]

21. Yang, W.R.; Ratinac, K.R.; Ringer, S.P.; Thordarson, P.; Gooding, J.J.; Braet, F. Carbon nanomaterials in biosensors: Should you use nanotubes or graphene? Angew. Chem. Int. Edit. 2010, 49, 2114-2138. [CrossRef]

22. Hoseinnejad, M.; Jafari, S.M.; Katouzian, I. Inorganic and metal nanoparticles and their antimicrobial activity in food packaging applications. Crit. Rev. Microbiol. 2018, 44, 161-181. [CrossRef]

23. Morais, L.D.; Macedo, E.V.; Granjeiro, J.M.; Delgado, I.F. Critical evaluation of migration studies of silver nanoparticles present in food packaging: A systematic review. Crit. Rev. Food Sci. Nutr. 2019. [CrossRef] [PubMed]

24. Yin, I.X.; Zhang, J.; Zhao, I.S.; Mei, M.L.; Li, Q.L.; Chu, C.H. The antibacterial mechanism of silver nanoparticles and its application in dentistry. Int. J. Nanomed. 2020, 15, 2555-2562. [CrossRef] [PubMed]

25. Mihai, M.M.; Dima, M.B.; Dima, B.; Holban, A.M. Nanomaterials for wound healing and infection control. Materials 2019, 12, 2176. [CrossRef] [PubMed]

26. Chan, K.L.; Mariatti, M.; Lockman, Z.; Sim, L.C. Effects of the Size and Filler Loading on the Properties of Copper- and Silver-Nanoparticle-Filled Epoxy Composites. J. Appl. Polym. Sci. 2011, 121, 3145-3152. [CrossRef]

27. Stamplecoskie, K.G.; Scaiano, J.C.; Tiwari, V.S.; Anis, H. Optimal size of silver nanoparticles for surface-enhanced raman spectroscopy. J. Phys. Chem. C 2011, 115, 1403-1409. [CrossRef]

28. Chinnapongse, S.L.; MacCuspie, R.I.; Hackley, V.A. Persistence of singly dispersed silver nanoparticles in natural freshwaters, synthetic seawater, and simulated estuarine waters. Sci. Total Environ. 2011, 409, 2443-2450. [CrossRef]

29. Zhang, P.; Shao, C.L.; Zhang, Z.Y.; Zhang, M.Y.; Mu, J.B.; Guo, Z.C.; Liu, Y.C. In Situ assembly of well-dispersed Ag nanoparticles (AgNPs) on electrospun carbon nanofibers (CNFs) for catalytic reduction of 4-nitrophenol. Nanoscale 2011, 3, 3357-3363. [CrossRef]

30. Karimzadeh, R.; Mansour, N. The effect of concentration on the thermo-optical properties of colloidal silver nanoparticles. Opt. Laser Technol. 2010, 42, 783-789. [CrossRef]

31. Lemire, J.A.; Harrison, J.J.; Turner, R.J. Antimicrobial activity of metals: Mechanisms, molecular targets and applications. Nat. Rev. Microbiol. 2013, 11, 371-384. [CrossRef] [PubMed]

32. Maillard, J.Y.; Hartemann, P. Silver as an antimicrobial: Facts and gaps in knowledge. Crit. Rev. Microbiol. 2013, 39, 373-383. [CrossRef] [PubMed] 
33. Liao, C.Z.; Li, Y.C.; Tjong, S.C. Bactericidal and cytotoxic properties of silver nanoparticles. Int. J. Mol. Sci. 2019, 20, 449. [CrossRef] [PubMed]

34. Balouiri, M.; Sadiki, M.; Ibnsouda, S.K. Methods for in vitro evaluating antimicrobial activity: A review. J. Pharm. Anal. 2016, 6, 71-79. [CrossRef] [PubMed]

35. van Belkum, A.; Dunne, W.M. Next-Generation antimicrobial susceptibility testing. J. Clin. Microbiol. 2013, 51, 2018-2024. [CrossRef]

36. Schumacher, A.; Vranken, T.; Malhotra, A.; Arts, J.J.C.; Habibovic, P. In Vitro antimicrobial susceptibility testing methods: Agar dilution to 3D tissue-engineered models. Eur. J. Clin. Microbiol. Infect. Dis. 2018, 37, 187-208. [CrossRef]

37. CLSI. Methods for Determining Bactericidal Activity of Antimicrobial Agents. Approved Standard, CLSI Document M26-A; Clinical and Laboratory Standards Institute: Wayne, PA, USA, 1999.

38. CLSI. Methods for Antimicrobial Susceptibility Testing of Anaerobic Bacteria. Approved Standard, CLSI Document M11-A7, 7th ed.; Clinical and Laboratory Standards Institute: Wayne, PA, USA, 2007.

39. CLSI. Methods for Dilution Antimicrobial Susceptibility Tests for Bacteria that Grow Aerobically. Approved Standard, CLSI Document M07-A9, 9th ed.; Clinical and Laboratory Standards Institute: Wayne, PA, USA, 2012.

40. Mady, O.Y.; Al-Madboly, L.A.; Donia, A.A. Preparation, and Assessment of Antidermatophyte Activity of Miconazole-Urea Water-Soluble Film. Front. Microbiol. 2020, 11, 16. [CrossRef] [PubMed]

41. Farha, A.K.; Yang, Q.Q.; Kim, G.; Zhang, D.; Mavumengwana, V.; Habimana, O.; Li, H.B.; Corke, H.; Gan, R.Y. Inhibition of multidrug-resistant foodborne Staphylococcus aureus biofilms by a natural terpenoid (+)-Nootkatone and related molecular mechanism. Food Control 2020, 112, 8. [CrossRef]

42. Lin, S.H.; Huang, R.X.; Cheng, Y.W.; Liu, J.; Lau, B.L.T.; Wiesner, M.R. Silver nanoparticle-alginate composite beads for point-of-use drinking water disinfection. Water Res. 2013, 47, 3959-3965. [CrossRef]

43. Lee, N.-Y.; Ko, W.-C.; Hsueh, P.-R. Nanoparticles in the treatment of infections caused by multidrug-resistant organisms. Front. Pharmacol. 2019, 10. [CrossRef]

44. Chugh, H.; Sood, D.; Chandra, I.; Tomar, V.; Dhawan, G.; Chandra, R. Role of gold and silver nanoparticles in cancer nano-medicine. Artif. Cell. Nanomed. Biotechnol. 2018, 46, S1210-S1220. [CrossRef] [PubMed]

45. Abbasi, E.; Milani, M.; Fekri, A.S.; Kouhi, M.; Akbarzadeh, A.; Tayefi, N.H.; Nikasa, P.; Joo, S.W.; Hanifehpour, Y.; Nejati-Koshki, K.; et al. Silver nanoparticles: Synthesis methods, bio-applications and properties. Crit. Rev. Microbiol. 2016, 42, 173-180. [CrossRef] [PubMed]

46. Saha, J.; Begum, A.; Mukherjee, A.; Kumar, S. A novel green synthesis of silver nanoparticles and their catalytic action in reduction of Methylene Blue dye. Sustain. Environ. Res. 2017, 27, 245-250. [CrossRef]

47. Vorobyova, V.; Vasyliev, G.; Skiba, M. Eco-Friendly "green" synthesis of silver nanoparticles with the black currant pomace extract and its antibacterial, electrochemical, and antioxidant activity. Appl. Nanosci. 2020, 12. [CrossRef]

48. Bindhu, M.R.; Umadevi, M.; Esmail, G.A.; Al-Dhabi, N.A.; Arasu, M.V. Green synthesis and characterization of silver nanoparticles from Moringa oleifera flower and assessment of antimicrobial and sensing properties. J. Photochem. Photobiol. B Biol. 2020, 205, 7. [CrossRef]

49. Jyoti, K.; Baunthiyal, M.; Singh, A. Characterization of silver nanoparticles synthesized using Urtica dioica linn. leaves and their synergistic effects with antibiotics. J. Radiat. Res. Appl. Sci. 2016, 9, 217-227. [CrossRef]

50. Chinnasamy, G.; Chandrasekharan, S.; Bhatnagar, S. Biosynthesis of silver nanoparticles from Melia azedarach: Enhancement of antibacterial, wound healing, antidiabetic and antioxidant activities. Int. J. Nanomed. 2019, 14, 9823-9836. [CrossRef]

51. Barbosa, A.; Silva, L.P.C.; Ferraz, C.M.; Tobias, F.L.; de Araujo, J.V.; Loureiro, B.; Braga, G.; Veloso, F.B.R.; Soares, F.E.D.; Fronza, M.; et al. Nematicidal activity of silver nanoparticles from the fungus duddingtonia flagrans. Int. J. Nanomed. 2019, 14, 2341-2348. [CrossRef]

52. Hamedi, S.; Shojaosadati, S.; Shokrollahzadeh, S.; Hashemi-Najafabadi, S. Extracellular biosynthesis of silver nanoparticles using a novel and non-pathogenic fungus, neurospora intermedia: Controlled synthesis and antibacterial activity. World J. Microbiol. Biotechnol. 2014, 30, 693-704. [CrossRef]

53. Saravanan, M.; Arokiyaraj, S.; Lakshmi, T.; Pugazhendhi, A. Synthesis of silver nanoparticles from phenerochaete chrysosporium (MTCC-787) and their antibacterial activity against human pathogenic bacteria. Microb. Pathog. 2018, 117, 68-72. [CrossRef]

54. Li, F.S.; Weng, J.K. Demystifying traditional herbal medicine with modern approaches. Nat. Plants $2017,3,7$. [CrossRef] [PubMed] 
55. Sehnal, K.; Hosnedlova, B.; Docekalova, M.; Stankova, M.; Uhlirova, D.; Tothova, Z.; Kepinska, M.; Milnerowicz, H.; Fernandez, C.; Ruttkay-Nedecky, B.; et al. An assessment of the effect of green synthesized silver nanoparticles using sage leaves (Salvia officinalis L.) on germinated plants of maize (Zea mays L.). Nanomaterials 2019, 9, 1550. [CrossRef] [PubMed]

56. Jia, X.W.; Yao, Y.C.; Yu, G.F.; Qu, L.L.; Li, T.X.; Li, Z.J.; Xu, C.P. Synthesis of gold-silver nanoalloys under microwave-assisted irradiation by deposition of silver on gold nanoclusters/triple helix glucan and antifungal activity. Carbohydr. Polym. 2020, 238, 7. [CrossRef] [PubMed]

57. Yu, Z.L.; Wang, W.; Dhital, R.; Kong, F.B.; Lin, M.S.; Mustaph, A. Antimicrobial effect and toxicity of cellulose nanofibril/silver nanoparticle nanocomposites prepared by an ultraviolet irradiation method. Colloid Surf. $B$ Biointerfaces 2019, 180, 212-220. [CrossRef] [PubMed]

58. Zhao, X.M.; Li, N.; Jing, M.L.; Zhang, Y.F.; Wang, W.; Liu, L.S.; Xu, Z.W.; Liu, L.Y.; Li, F.Y.; Wu, N. Monodispersed and spherical silver nanoparticles/graphene nanocomposites from gamma-ray assisted in-situ synthesis for nitrite electrochemical sensing. Electrochim. Acta 2019, 295, 434-443. [CrossRef]

59. Haleem, A.; Chen, J.; Guo, X.X.; Wang, J.Y.; Li, H.J.; Li, P.Y.; Chen, S.Q.; He, W.D. Hybrid cryogels composed of P(NIPAM-co-AMPS) and metal nanoparticles for rapid reduction of $p$-nitrophenol. Polymer 2020, 193, 10. [CrossRef]

60. Liang, M.; Su, R.X.; Huang, R.L.; Qi, W.; Yu, Y.J.; Wang, L.B.; He, Z.M. Facile in situ synthesis of silver nanoparticles on procyanidin-grafted eggshell membrane and their catalytic properties. ACS Appl. Mater. Interfaces 2014, 6, 4638-4649. [CrossRef]

61. Cao, X.L.; Tang, M.; Liu, F.; Nie, Y.Y.; Zhao, C.S. Immobilization of silver nanoparticles onto sulfonated polyethersulfone membranes as antibacterial materials. Colloid Surf. B Biointerfaces 2010, 81, 555-562. [CrossRef]

62. Hanif, Z.; Khan, Z.A.; Siddiqui, M.F.; Tariq, M.Z.; Park, S.; Park, S.J. Tannic acid-mediated rapid layer-by-layer deposited non-leaching silver nanoparticles hybridized cellulose membranes for point-of-use water disinfection. Carbohydr. Polym. 2020, 231, 8. [CrossRef]

63. Dong, X.B.; Shannon, H.D.; Amirsoleimani, A.; Brion, G.M.; Escobar, I.C. Thiol-Affinity immobilization of casein-coated silver nanoparticles on polymeric membranes for biofouling control. Polymers 2019, 11, 2057. [CrossRef]

64. Hirsch, U.M.; Teuscher, N.; Ruhl, M.; Heilmann, A. Plasma-Enhanced magnetron sputtering of silver nanoparticles on reverse osmosis membranes for improved antifouling properties. Surf. Interfaces 2019, 16, 1-7. [CrossRef]

65. Saraswathi, M.; Rana, D.; Alwarappan, S.; Gowrishankar, S.; Vijayakumar, P.; Nagendran, A. Polydopamine layered poly (ether imide) ultrafiltration membranes tailored with silver nanoparticles designed for better permeability, selectivity and antifouling. J. Ind. Eng. Chem. 2019, 76, 141-149. [CrossRef]

66. Yang, G.; Xie, J.; Hong, F.; Cao, Z.; Yang, X. Antimicrobial activity of silver nanoparticle impregnated bacterial cellulose membrane: Effect of fermentation carbon sources of bacterial cellulose. Carbohydr. Polym. 2012, 87, 839-845. [CrossRef]

67. Levi-Polyachenko, N.; Jacob, R.; Day, C.; Kuthirummal, N. Chitosan wound dressing with hexagonal silver nanoparticles for hyperthermia and enhanced delivery of small molecules. Colloids Surf. B Biointerfaces 2016, 142, 315-324. [CrossRef] [PubMed]

68. Archana, D.; Singh, B.K.; Dutta, J.; Dutta, P.K. Chitosan-PVP-nano silver oxide wound dressing: In Vitro and in vivo evaluation. Int. J. Biol. Macromol. 2015, 73, 49-57. [CrossRef]

69. Madhumathi, K.; Sudheesh, K.P.T.; Abhilash, S.; Sreeja, V.; Tamura, H.; Manzoor, K.; Nair, S.V.; Jayakumar, R. Development of novel chitin/nanosilver composite scaffolds for wound dressing applications. J. Mater. Sci. Mater. Med. 2010, 21, 807-813. [CrossRef]

70. Maneerung, T.; Tokura, S.; Rujiravanit, R. Impregnation of silver nanoparticles into bacterial cellulose for antimicrobial wound dressing. Carbohydr. Polym. 2008, 72, 43-51. [CrossRef]

71. Chen, H.; Lan, G.; Ran, L.; Xiao, Y.; Yu, K.; Lu, B.; Dai, F.; Wu, D.; Lu, F. A novel wound dressing based on a Konjac glucomannan/silver nanoparticle composite sponge effectively kills bacteria and accelerates wound healing. Carbohydr. Polym. 2018, 183, 70-80. [CrossRef]

72. Ahamed, M.I.; Sankar, S.; Kashif, P.M.; Basha, S.K.; Sastry, T.P. Evaluation of biomaterial containing regenerated cellulose and chitosan incorporated with silver nanoparticles. Int. J. Biol. Macromol. 2015, 72, 680-686. [CrossRef] 
73. Kanikireddy, V.; Yallapu, M.; Varaprasad, K.; Nagireddy, N.; Ravindra, S.; Neppalli, S.; Raju, K. Fabrication of Curcumin Encapsulated Chitosan-PVA Silver Nanocomposite Films for Improved Antimicrobial Activity. J. Biomater. Nanobiotechnol. 2011, 2, 55-64. [CrossRef]

74. Hu, W.; Chen, S.; Li, X.; Shi, S.; Shen, W.; Zhang, X.; Wang, H. In Situ synthesis of silver chloride nanoparticles into bacterial cellulose membranes. Mater. Sci. Eng. C 2009, 29, 1216-1219. [CrossRef]

75. Singh, R.; Singh, D. Chitin membranes containing silver nanoparticles for wound dressing application. Int. Wound J. 2014, 11, 264-268. [CrossRef] [PubMed]

76. Wu, J.; Zheng, Y.; Song, W.; Luan, J.; Wen, X.; Wu, Z.; Chen, X.; Wang, Q.; Guo, S. In Situ synthesis of silver-nanoparticles/bacterial cellulose composites for slow-released antimicrobial wound dressing. Carbohydr. Polym. 2014, 102, 762-771. [CrossRef] [PubMed]

77. Hebeish, A.; El-Rafie, M.H.; El-Sheikh, M.A.; Seleem, A.A.; El-Naggar, M.E. Antimicrobial wound dressing and anti-inflammatory efficacy of silver nanoparticles. Int. J. Biol. Macromol. 2014, 65, 509-515. [CrossRef]

78. Tian, J.; Wong, K.; Ho, C.-M.; Lok, C.-N.; Yu, W.-Y.; Che, C.-M.; Chiu, J.-F.; Tam, P. Topical Delivery of Silver Nanoparticles Promotes Wound Healing. ChemMedChem 2007, 2, 129-136. [CrossRef]

79. Duran, N.; Marcato, P.; Souza, G.; Alves, O.; Esposito, E. Antibacterial Effect of Silver Nanoparticles Produced by Fungal Process on Textile Fabrics and Their Effluent Treatment. J. Biomed. Nanotechnol. 2007, 3, $203-208$. [CrossRef]

80. Sundaramoorthi, C.; Mathews, D.; Sivanandy, D.P.; Kalaiselvan, V.; Rajasekaran, A. Biosynthesis of silver nanoparticles from Aspergillus niger and evaluation of its wound healing activity in experimental rat model. Int. J. PharmTech Res. 2009, 1, 1523-1529.

81. Chen, X.; Lin, H.T.; Xu, T.T.; Lai, K.Q.; Han, X.; Lin, M.S. Cellulose nanofibers coated with silver nanoparticles as a flexible nanocomposite for measurement of flusilazole residues in Oolong tea by surface-enhanced Raman spectroscopy. Food Chem. 2020, 315, 7. [CrossRef]

82. Yun, B.J.; Koh, W.G. Highly-Sensitive SERS-based immunoassay platform prepared on silver nanoparticle-decorated electrospun polymeric fibers. J. Ind. Eng. Chem. 2020, 82, 341-348. [CrossRef]

83. Shen, B.L.; Zhang, D.Y.; Wei, Y.J.; Zhao, Z.H.; Ma, X.F.; Zhao, X.D.; Wang, S.; Yang, W.X. Preparation of Ag Doped Keratin/PA6 Nanofiber Membrane with Enhanced Air Filtration and Antimicrobial Properties. Polymers 2019, 11, 1511. [CrossRef]

84. Dou, J.L.; Zhu, G.D.; Hu, B.; Yang, J.M.; Ge, Y.X.; Li, X.; Liu, J.Y. Wall thickness-tunable AgNPs-NCNTs for hydrogen peroxide sensing and oxygen reduction reaction. Electrochim. Acta 2019, 306, 466-476. [CrossRef]

85. Rath, G.; Hussain, T.; Chauhan, G.; Garg, T.; Goyal, A.K. Collagen nanofiber containing silver nanoparticles for improved wound-healing applications. J. Drug Target. 2016, 24, 520-529. [CrossRef] [PubMed]

86. Jin, W.-J.; Lee, H.; Jeong, E.; Park, W.H.; Youk, J. Preparation of Polymer Nanofibers Containing Silver Nanoparticles by Using Poly(N-vinylpyrrolidone). Macromol. Rapid Comm. 2005, 26, 1903-1907. [CrossRef]

87. Ghavaminejad, A.; Unnithan, R.A.; Ramachandra, K.S.A.; Samarikhalaj, M.; Thomas, R.; Jeong, Y.; Nasseri, S.; Murugesan, P.; Wu, D.; Park, C.; et al. Mussel-Inspired Electrospun Nanofibers Functionalized with Size Controlled Silver Nanoparticles for Wound Dressing Application. ACS Appl. Mater. Interf. 2015, 7. [CrossRef] [PubMed]

88. Natarajan, D.; Lakra, R.; Srivatsan, K.; Usha, R.; Korrapati, P.; Kiran, M. Plumbagin caged silver nanoparticle stabilized collagen scaffold for wound dressing. J. Mater. Chem. B 2014, 3. [CrossRef]

89. Rujitanaroj, P.-O.; Pimpha, N.; Supaphol, P. Wound-Dressing materials with antibacterial activity from electrospun gelatin fiber mats containing silver nanoparticles. Polymer 2008, 49, 4723-4732. [CrossRef]

90. Dubey, P.; Bhushan, B.; Sachdev, A.; Matai, I.; Kumar, U.; Packirisamy, G. Silver-Nanoparticle-Incorporated composite nanofibers for potential wound-dressing applications. J. Appl. Polymer Sci. 2015, 132. [CrossRef]

91. Neibert, K.; Gopishetty, V.; Grigoryev, A.; Tokarev, I.; Al-Hajaj, N.; Vorstenbosch, J.; Philip, A.; Minko, S.; Maysinger, D. Wound-Healing with mechanically robust and biodegradable hydrogel fibers loaded with silver nanoparticles. Adv. Healthc. Mater. 2012, 1, 621-630. [CrossRef]

92. Abdelgawad, A.M.; Hudson, S.M.; Rojas, O.J. Antimicrobial wound dressing nanofiber mats from multicomponent (chitosan/silver-NPs/polyvinyl alcohol) systems. Carbohydr. Polym. 2014, 100, 166-178. [CrossRef]

93. El-Aassar, M.R.; Ibrahim, O.M.; Fouda, M.M.G.; El-Beheri, N.G.; Agwa, M.M. Wound healing of nanofiber comprising Polygalacturonic/Hyaluronic acid embedded silver nanoparticles: In-Vitro and in-vivo studies. Carbohydr. Polym. 2020, 238, 11. [CrossRef] 
94. Augustine, R.; Kalarikkal, N.; Thomas, S. Electrospun PCL membranes incorporated with biosynthesized silver nanoparticles as antibacterial wound dressings. Appl. Nanosci. 2016, 6, 337-344. [CrossRef]

95. Uttayarat, P.; Jetawattana, S.; Suwanmala, P.; Eamsiri, J.; Tangthong, T.; Pongpat, S. Antimicrobial electrospun silk fibroin mats with silver nanoparticles for wound dressing application. Fiber. Polymer. 2012, 13, 999-1006. [CrossRef]

96. Saberi, A.; Sadeghi, M.; Alipour, E. Design of AgNPs-Base Starch/PEG-Poly (Acrylic Acid) Hydrogel for Removal of Mercury (II). J. Polym. Environ. 2020, 28, 906-917. [CrossRef]

97. Dil, N.N.; Sadeghi, M. Free radical synthesis of nanosilver/gelatin-poly (acrylic acid) nanocomposite hydrogels employed for antibacterial activity and removal of $\mathrm{Cu}$ (II) metal ions. J. Hazard. Mater. 2018, 351, 38-53. [CrossRef] [PubMed]

98. Varaprasad, K.; Yallapu, M.; Ravindra, S.; Nagireddy, N.; Kanikireddy, V.; Monika, K.; Bojja, S.; Raju, K. Hydrogel-Silver nanoparticle composites: A new generation of antimicrobials. J. Appl. Polymer Sci. 2010, 115, 1199-1207. [CrossRef]

99. Kumar, P.T.S.; Abhilash, S.; Manzoor, K.; Nair, S.V.; Tamura, H.; Jayakumar, R. Preparation and characterization of novel $\beta$-chitin/nanosilver composite scaffolds for wound dressing applications. Carbohydr. Polym. 2010, 80, 761-767. [CrossRef]

100. Verma, J.; Kanoujia, J.; Parashar, P.; Tripathi, C.B.; Saraf, S.A. Wound healing applications of sericin/chitosan-capped silver nanoparticles incorporated hydrogel. Drug Deliv. Translat. Res. 2017, 7,77-88. [CrossRef]

101. Boonkaew, B.; Kempf, M.; Kimble, R.; Supaphol, P.; Cuttle, L. Antimicrobial efficacy of a novel silver hydrogel dressing compared to two common silver burn wound dressings: Acticoat ${ }^{\mathrm{TM}}$ and PolyMem Silver ${ }^{\circledR}$. Burns 2014, 40, 89-96. [CrossRef]

102. Oliveira, R.N.; Rouze, R.; Quilty, B.; Alves, G.G.; Soares, G.D.; Thire, R.M.; McGuinness, G.B. Mechanical properties and in vitro characterization of polyvinyl alcohol-nano-silver hydrogel wound dressings. Interface Focus 2014, 4. [CrossRef]

103. Rattanaruengsrikul, V.; Pimpha, N.; Supaphol, P. In Vitro efficacy and toxicology evaluation of silver nanoparticle-loaded gelatin hydrogel pads as antibacterial wound dressings. J. Appl. Polymer. Sci. 2012, 124. [CrossRef]

104. Das, A.; Kumar, A.; Patil, N.B.; Viswanathan, C.; Ghosh, D. Preparation and characterization of silver nanoparticle loaded amorphous hydrogel of carboxymethylcellulose for infected wounds. Carbohydr. Polym. 2015, 130, 254-261. [CrossRef] [PubMed]

105. Liu, X.; Lee, P.Y.; Ho, C.M.; Lui, V.C.; Chen, Y.; Che, C.M.; Tam, P.K.; Wong, K.K. Silver nanoparticles mediate differential responses in keratinocytes and fibroblasts during skin wound healing. ChemMedChem 2010, 5, 468-475. [CrossRef] [PubMed]

106. Pinto, R.M.; Lopes-de-Campos, D.; Martins, M.C.L.; Van Dijck, P.; Nunes, C.; Reis, S. Impact of nanosystems in Staphylococcus aureus biofilms treatment. FEMS Microbiol. Rev. 2019, 43, 622-641. [CrossRef] [PubMed]

107. Gopinath, P.; Gogoi, S.K.; Chattopadhyay, A.; Ghosh, S.S. Implications of silver nanoparticle induced cell apoptosis for in vitro gene therapy. Nanotechnology 2008, 19, 075104. [CrossRef] [PubMed]

108. Borm, P.J.; Kreyling, W. Toxicological hazards of inhaled nanoparticles-Potential implications for drug delivery. J. Nanosci. Nanotechnol. 2004, 4, 521-531. [CrossRef] [PubMed]

109. McAuliffe, M.E.; Perry, M.J. Are nanoparticles potential male reproductive toxicants? A literature review. Nanotoxicology 2007, 1, 204-210. [CrossRef]

110. Hussain, S.M.; Javorina, A.K.; Schrand, A.M.; Duhart, H.M.; Ali, S.F.; Schlager, J.J. The interaction of manganese nanoparticles with PC-12 cells induces dopamine depletion. Toxicol. Sci. 2006, 92, 456-463. [CrossRef]

111. Hussain, S.; Hess, K.; Gearhart, J.; Geiss, K.; Schlager, J. In Vitro toxicity of nanoparticles in BRL 3A rat liver cells. Toxicol. Vitr. 2005, 19, 975-983. [CrossRef]

112. Braydich-Stolle, L.; Hussain, S.; Schlager, J.J.; Hofmann, M.-C. In Vitro cytotoxicity of nanoparticles in mammalian germline stem cells. Toxicol. Sci. 2005, 88, 412-419. [CrossRef]

113. Chen, K.; Wang, F.; Liu, S.; Wu, X.; Xu, L.; Zhang, D. In Situ reduction of silver nanoparticles by sodium alginate to obtain silver-loaded composite wound dressing with enhanced mechanical and antimicrobial property. Internatl. J. Biol. Macromol. 2020, 148, 501-509. [CrossRef] 
114. Ip, M.; Lui, S.L.; Poon, V.K.; Lung, I.; Burd, A. Antimicrobial activities of silver dressings: An in vitro comparison. J. Med. Microbiol. 2006, 55, 59-63. [CrossRef] [PubMed]

115. Sarkar, S.; Jana, A.D.; Samanta, S.K.; Mostafa, G. Facile synthesis of silver nano particles with highly efficient anti-microbial property. Polyhedron 2007, 26, 4419-4426. [CrossRef]

116. Kokura, S.; Handa, O.; Takagi, T.; Ishikawa, T.; Naito, Y.; Yoshikawa, T. Silver nanoparticles as a safe preservative for use in cosmetics. Nanomed. Nanotechnol. Biol. Med. 2010, 6, 570-574. [CrossRef] [PubMed]

117. Yang, Y.; Qin, Z.; Zeng, W.; Yang, T.; Cao, Y.; Mei, C.; Kuang, Y. Toxicity assessment of nanoparticles in various systems and organs. Nanotechnol. Rev. 2017, 6, 279-289. [CrossRef]

118. Zewde, B.; Ambaye, A.; Stubbs Iii, J.; Raghavan, D. A review of stabilized silver nanoparticles-synthesis, biological properties, characterization, and potential areas of applications. Nanomed 2016, 4, 1-14.

119. Rai, M.; Deshmukh, S.; Ingle, A.; Gade, A. Silver nanoparticles: The powerful nanoweapon against multidrug-resistant bacteria. J. Appl. Microbiol. 2012, 112, 841-852. [CrossRef]

120. Atiyeh, B.S.; Costagliola, M.; Hayek, S.N.; Dibo, S.A. Effect of silver on burn wound infection control and healing: Review of the literature. Burns 2007, 33, 139-148. [CrossRef]

121. Franková, J.; Pivodová, V.; Vágnerová, H.; Juráňová, J.; Ulrichová, J. Effects of silver nanoparticles on primary cell cultures of fibroblasts and keratinocytes in a wound-healing model. J. Appl. Biomater. Funct. Mater. 2016, 14, 137-142. [CrossRef]

122. Resmi, R.; Unnikrishnan, S.; Krishnan, L.K.; Kalliyana, K.V. Synthesis and characterization of silver nanoparticle incorporated gelatin-hydroxypropyl methacrylate hydrogels for wound dressing applications. J. Appl. Polym. Sci. 2017, 134, 44529. [CrossRef]

123. Kalantari, K.; Mostafavi, E.; Afifi, A.M.; Izadiyan, Z.; Jahangirian, H.; Rafiee-Moghaddam, R.; Webster, T.J. Wound dressings functionalized with silver nanoparticles: Promises and pitfalls. Nanoscale 2020, 12, 2268-2291. [CrossRef]

124. Szegedi, Á.; Popova, M.; Yoncheva, K.; Makk, J.; Mihály, J.; Shestakova, P. Silver-and sulfadiazine-loaded nanostructured silica materials as potential replacement of silver sulfadiazine. J. Mater. Chem. B 2014, 2, 6283-6292. [CrossRef] [PubMed]

125. Walker, M.; Cochrane, C.A.; Bowler, P.G.; Parsons, D.; Bradshaw, P. Silver deposition and tissue staining associated with wound dressings containing silver. Ostomy Wound Manag. 2006, 52, 42.

126. Trop, M.; Novak, M.; Rodl, S.; Hellbom, B.; Kroell, W.; Goessler, W. Silver-Coated dressing acticoat caused raised liver enzymes and argyria-like symptoms in burn patient. J. Trauma Acute Care Surg. 2006, 60, 648-652. [CrossRef] [PubMed]

127. Anisha, B.; Biswas, R.; Chennazhi, K.; Jayakumar, R. Chitosan-Hyaluronic acid/nano silver composite sponges for drug resistant bacteria infected diabetic wounds. Internatl. J. Biol. Macromol. 2013, 62, 310-320. [CrossRef] [PubMed]

128. Nam, G.; Rangasamy, S.; Purushothaman, B.; Song, J.M. The application of bactericidal silver nanoparticles in wound treatment. Nanomate. Nanotechnol. 2015, 5, 5-23. [CrossRef]

129. Burd, A.; Kwok, C.H.; Hung, S.C.; Chan, H.S.; Gu, H.; Lam, W.K.; Huang, L. A comparative study of the cytotoxicity of silver-based dressings in monolayer cell, tissue explant, and animal models. Wound Repair Regener. 2007, 15, 94-104. [CrossRef] [PubMed]

(C) 2020 by the authors. Licensee MDPI, Basel, Switzerland. This article is an open access article distributed under the terms and conditions of the Creative Commons Attribution (CC BY) license (http://creativecommons.org/licenses/by/4.0/). 